\title{
Volume, formation and sedimentation of future glacier lakes in Switzerland
}

\author{
Tim Steffen ${ }^{1,2}$, Matthias Huss ${ }^{1,2,3}$, Rebekka Estermann ${ }^{1,2}$, Elias Hodel ${ }^{1,2}$, Daniel Farinotti ${ }^{1,2}$ \\ ${ }^{1}$ Laboratory of Hydraulics, Hydrology and Glaciology (VAW), ETH Zurich, Zurich, 8092, Switzerland \\ $5 \quad{ }^{2}$ Swiss Federal Institute for Forest, Snow and Landscape Research (WSL), Birmensdorf, 8903, Switzerland \\ ${ }^{3}$ Department of Geosciences, University of Fribourg, Fribourg, 1700, Switzerland \\ Correspondence to: Daniel Farinotti (daniel.farinotti@ethz.ch)
}

Abstract. Ongoing climate change and associated glacier retreat is causing rapid environmental change, including shifts in high-alpine landscapes. Glacier lakes, which can form in topographical depressions left behind by glacier retreat, are prominent features within such landscapes. Whilst model-based estimates for the number and area of future glacier lakes exist for various mountain regions across the world, the exact morphology and temporal evolution remain largely unassessed. Here, we leverage a recently released, measurement-based estimate for the subglacial topography of all glaciers in the Swiss Alps, to provide an estimate about the number, size, time of emergence, as well as sediment infill of future glacier lakes. The topographical information is based on 2,450 km measured ice thickness profiles, whilst the temporal evolution of glaciers is obtained from a glacier evolution model forced with an ensemble of climate projections. We estimate that up to 683 potential lakes with an area $>5,000 \mathrm{~m}^{2}$ and a depth $>5 \mathrm{~m}$ could emerge across the Swiss Alps if glaciers were to disappear completely, with the potential to hold a total water volume of up to $1.16[1.05,1.32] \mathrm{km}^{3}$ (numbers and 95\% confidence interval). For a middle-of-the-road climate scenario, we estimate that about $10 \%(0.12$ [0.04, $\left.0.18] \mathrm{km}^{3}\right)$ and $48 \%\left(0.56[0.26,0.67] \mathrm{km}^{3}\right)$ of this volume could be realized by 2050 and 2100 , respectively. In a firstorder assessment, we also estimate that ca. $45 \%$ of the newly emerging glacier lakes (260 out of 570) will be transient features, i.e. will disappear again before the end of the century owing to refilling with sediments released by glacial erosion and proglacial sediment transport.

\section{Introduction}

As global temperatures continue to rise, worldwide mountain glaciers are rapidly shrinking (Hock et al., 2019). Also glaciers in the Alps are affected, with further loss of glacier volumes being inevitable (Marzeion et al., 2018; Zekollari et al., 2020). Depending on climate scenario, the Alps may lose up to $94 \%$ of their 2020 ice volume by the end of the $21^{\text {st }}$ century (Zekollari et al., 2019), with important consequences for the appearance of landscapes as such (Orlove et al., 2008). Retreating glaciers produce environments dominated by erosion and deposition, consisting of hills, sinks, and overdeepenings amongst other (e.g. Cook and Swift, 2012). Overdeepenings, i.e. confined topographical depressions caused by erosion, may entirely replenish with sediments transported by glaciers and their proglacial streams, or may fill 
https://doi.org/10.5194/esurf-2022-12

Preprint. Discussion started: 1 March 2022

(c) Author(s) 2022. CC BY 4.0 License.

with water giving rise to new glacier lakes (Frey et al., 2010; Mölg et al., 2021). Predicting which of the two scenarios will materialize is difficult, since the spatio-temporal dynamics of glacial erosion is governed by a complex interplay of processes that are difficult to quantify and, thus, to anticipate (e.g. Lane et al., 2017). In their recent review, Carrivick and Tweed (2021) highlighted that at the worldwide scale, specific sediment yields from glacierized catchments can span as much as five orders of magnitude, with sediment yields in the European Alps ranging from dozens to thousands of tons per year and square kilometre. Moreover, the sediment yields are strongly controlled by glacierization itself (Hinderer et al., 2013), adding a significant temporal dependence on the corresponding estimates.

Despite the difficulty in predicting their emergence, the interest in potential new glacier lakes has recently been on the rise. Indeed, such lakes have been identified to pose both risks and opportunities (Haeberli et al., 2016; Anacona et al., 2018). On the one hand glacier lakes represent a potential hazard for downslope populations and infrastructure if they burst (Frey et al., 2010; Emmer et al, 2014; Anacona et al., 2018), with a number of studies aiming at identifying already-existing hazardous lakes (e.g. Bolch et al., 2012; Huggel et al. 2002; Veh et al., 2018; Zhang et al., 2022) and at clarifying whether any change in the frequency of their outbursts can be detected at large scales (e.g. Veh et al., 2019). On the other hand, new glacier lakes are of relevance for high-mountain biodiversity (Čiamporová-Zat'ovičová and Čiampor, 2017; Tiberti et al., 2019), have been shown to hold significant hydropower potential (Ehrbar et al., 2018; Farinotti, et al., 2019), might be attractive to tourists (Purdie, 2013; Welling et al., 2015), or might serve as reservoirs for artificial snow production in ski areas (Haeberli et al., 2016) and other water management purposes (Farinotti et al., 2016; Brunner et al., 2019).

In light of the above relevance, accurate knowledge about the size, the distribution, and the time of formation of glacier lakes is key. At the worldwide scale, there are multiple examples of inventories of already-existing glacier lakes (e.g. Komori, 2008; Gardelle et al., 2011; Zhang et al., 2015; Emmer et al., 2016; Petrov et al., 2017; Drenkhan et al., 2018; Shugar et al., 2020; Wang et al., 2020), with most studies concurring that the formation of glacier lakes has been accelerating during the past decades (see also the review by Carrivick and Tweed, 2013). In the European Alps, inventories of existing proglacial lakes are available for Austria (Emmer et al., 2015; Buckel et al., 2018), various parts of Italy (Galluccio, 1998; Salerno et al., 2014; Viani et al., 2016), and Switzerland (Mölg et al., 2021). According to the latter, Switzerland hosted 987 proglacial lakes in 2016, covering an area of $6.22 \pm 0.25 \mathrm{~km}^{2}$ in total. Additional 205 glacier lakes have been fully replenished with sediments since 1850 and have thus disappeared again (Mölg et al., 2021). These numbers show that the emergence and disappearance of glacier lakes is a dynamic process, and calls for anticipating the location and timing of future glacier lakes as well.

Several studies aiming at such an anticipation of future glacier lakes exist, notably for (parts of) High Mountain Asia (Linsbauer et al., 2016; Kapitsa et al., 2017; Zheng et al., 2021), the Andes (Colonia et al., 2017; Drenkhan et al., 2018), or the European Alps (Linsbauer et al., 2012; Magnin et al., 2020; Viani et al., 2020; Gharehchahi et al., 2020). For the Swiss Alps, Linsbauer et al. (2012) estimated that between 400 and 600 new glacier lakes could form if glaciers were to vanish entirely, with a total area in the order of 50 to $60 \mathrm{~km}^{2}$ and a total volume of about $2 \mathrm{~km}^{3}$. Gharehchahi et al. (2020), who 
https://doi.org/10.5194/esurf-2022-12

Preprint. Discussion started: 1 March 2022

(c) Author(s) 2022. CC BY 4.0 License.

focused on the Swiss part of the Rhone basin, anticipated up to 171 potential new glacier lakes in this area, with a total volume of about $0.5 \mathrm{~km}^{3}$. Such studies are based on estimates of the subglacial topography and the assumption that any present-day subglacial overdeepening will form a lake once the glacier will have retreated from the corresponding location. The latter assumption ignores any topography changes that could emerge from sediment erosion and deposition, whilst the subglacial topography is inferred by subtracting a spatially-distributed estimate of the glacier ice thickness from contemporaneous information of the glacier surface topography. Since direct measurements of glacier ice thickness are generally sparse (Welty et al., 2020), glacier-wide ice thickness distributions are typically inferred with the help of inversion models (for a review , see Farinotti et al., 2017). The accuracy of such models has been assessed in two recent intercomparison experiments (Farinotti et al., 2017; 2021) with the results highlighting that such models are indeed skilful in estimating the glacier-wide ice thickness, but that point-based estimates can suffer from considerable uncertainties when at a certain distance from direct measurements. For glaciers with such measurements, the Ice Thickness Models Intercomparison eXperiment Phase 2 (ITMIX2; Farinotti et al., 2021) estimated a point-based uncertainty in the order of $16 \%$ of the mean glacier thickness. Clearly, this uncertainty directly affects the estimates for the location and size of potential future glacier lakes, and indicates that extensive ice thickness surveys are necessary for estimating the characteristics of potential future lakes with some confidence.

In this study, we rely on such extensive ice thickness surveys to present a new estimate for the potential formation of future glacier lakes in the Swiss Alps. More specifically, we rely on the Swiss-wide subglacial topography recently released by Grab et al. (2021) on the basis of almost 2,500 km of ground penetrating radar (GPR) surveys, and use it to detect the location and size of subglacial overdeepenings that could give rise to glacier lakes after their retreat. In contrast to previous studies, we also quantify the timing of the potential lake formation. We do so by combing the ice-free subglacial topography with results from the Global Glacier Evolution Model (GloGEM; Huss and Hock, 2015) forced by state-of-theart climate model projections. This provides insights into the water volumes that could be retained in future glacier lakes under different climate scenarios. For the first time, we also aim at roughly quantifying future sedimentation rates which affect the overdeepenings after glacier retreat, thus providing indications for the long-term persistence of the emerging lakes. The resulting estimates for the temporal evolution of future glacier lakes provide a first glimpse on how Alpine landscapes might change throughout the $21^{\text {st }}$ century.

\section{Study region and data}

The geographical extent of this study is given by the Swiss Glacier Inventory 2016 (SGI2016; Linsbauer et al., 2021), 95 which can be divided into the four large river catchments of Switzerland, i.e. Rhine, Rhone, Po, and Inn (Fig. 1). The SGI2016 is an inventory of all Swiss glaciers which has been produced on the basis of high-resolution aerial images acquired between 2013 and 2018 (centre year: 2016). The 1,400 inventoried glaciers cover an area of $961 \mathrm{~km}^{2}$. Most 
https://doi.org/10.5194/esurf-2022-12

Preprint. Discussion started: 1 March 2022

(c) Author(s) 2022. CC BY 4.0 License.

glaciers are small, with only 16 glaciers being larger than $10 \mathrm{~km}^{2}$. Eleven of the latter are situated in the Rhone river basin (Fig. 1) as it hosts the highest peaks of the Swiss Alps. The surface topography of each glacier is taken from the digital elevation model (DEM) swissALTI3D (Swisstopo, 2019), which refers to the year 2015 on average. For this study, SwissALTI3D has been resampled to a $10 \mathrm{~m}$ spatial resolution (the native resolution is $2 \mathrm{~m}$ ).

The subglacial topography of all considered glaciers is taken from Grab et al. (2021). This topography is based on both extensive helicopter-borne GPR measurements (Rutishauser et al., 2016; Langhammer et al., 2019a, 2019b) and groundbased GPR data. In total, 2,450 km of GPR profiles collected on 251 different glaciers and covering 81\% of the SGI2016 glacier area were available (cf. Table 1 in Grab et al, 2021). Since the density of the GPR measurements varies between glaciers and since direct ice thickness measurements are not available for all glaciers, Grab et al. (2021) used two different ice thickness models to obtain a spatially complete estimate: the Glacier Thickness Estimates model (GlaTE; Langhammer et al., 2019a) and the Ice Thickness and Volume Estimation based on Observations model (ITVEO; Huss \& Farinotti, 2012). Both of these models are based on principles of ice flow dynamics and are designed to optimally make use of the information contained within sparse measurements of ice thickness. The performance of both models has been assessed within ITMIX2 (Farinotti et al., 2021) and since the average of several ice thickness models has been shown to yield most robust results (Farinotti et al., 2017), the final dataset was obtained by averaging the ice thicknesses estimated by GlaTE and ITVEO. Henceforth we will refer to the subglacial topography obtained by subtracting this average ice thickness from the SwissALTI3D surface topography as to the "mean bedrock topography". The spatial resolution of this topography is of $10 \mathrm{~m}$, whilst an estimate for the local vertical accuracy (based on the distance to the next GPR measurement and the difference between the estimates of GlaTE and ITVEO) is provided as separate information to the dataset. For further details on the methodology, refer to Grab et al. (2021).

Our detection of potential lakes within the glacier extent of the SGI2016 is based on the abovementioned mean bedrock topography. Following previous studies, we define potential lakes through the detection of overdeepenings in the subglacial topography, i.e. we only consider bedrock-dammed lakes and neglect potential ice-dammed lakes or lakes dammed by moraines not resolved by the GPR data. The overdeepenings are detected by applying the tool "Fill" from the ArcGIS "Hydrology Toolset" (Esri, 2020) to the mean bedrock topography. This operation yields a spatially distributed dataset in which every overdeepening within the currently glacierized area is filled. We assume the difference between this dataset and the original mean bedrock topography to represent the depth of potential future glacier lakes, and detect their extents by drawing polygons around connected areas with depth $>0 \mathrm{~m}$. The latter operation is performed by using the ArcGIS tool "Raster to Polygon (Conversion)" (Esri, 2020). Only polygons with an area $>5,000 \mathrm{~m}^{2}$ and a maximal depth $>5 \mathrm{~m}$ are retained for further analysis. These thresholds were arbitrarily set and are meant to remove small-scale features that lie within the uncertainty of the underlying bedrock.

Being constrained to the area within the SGI2016 glacier outlines, the above procedure fails to identify already-existing glacier lakes that are in contact with glacier ice and that might further expand in future (one of the most prominent 
https://doi.org/10.5194/esurf-2022-12

Preprint. Discussion started: 1 March 2022

(c) Author(s) 2022. CC BY 4.0 License.

examples is the lake presently in front of Rhonegletscher, at the source of the Rhone river). To include such cases in our analyses, we visually inspected aerial images from Swisstopo (Swisstopo, 2021). We detected 15 lakes that are presently in contact with ice but are dammed by rock or sediment. To include them, we manually extended the lake polygons obtained with the procedure described above as. Since the bathymetry of the so-added lake portions is generally unknown, we pragmatically assumed their depth to be equal to the mean depth of the remaining lake portion (i.e. the lake portion that is presently glacierized and that has a depth estimate based on the available ice thickness information).

To distinguish between individual lakes, a lake identifier (lake-ID) is defined. The lake-ID is composed of the SGI-ID (i.e. the glacier identifier of the SGI2016) followed by the rank of the lake volume within the particular glacier. That is: the largest lake of the glacier with SGI-ID "B40-07" (that is Fieschergletscher), is named "B40-07-01", the second largest is named "B40-07-02", and so on. This nomenclature is used throughout the article and in the data that we provide as digital supplement (see section "Data availability”).

\subsection{Glacier retreat and timing of lake formation}

For estimating the timing of future lake formation, we rely on glacier retreat projections scenarios based on GloGEM (Huss and Hock, 2015). The model describes the main processes determining glacier surface mass balance (snow accumulation, ice melt, refreezing) and computes annual surface elevation change - and thus glacier retreat or advance - based on a massconserving parameterization (Huss et al., 2010). The mean bedrock topography by Grab et al. (2021) is used for determining the current ice thickness distribution, and the model has been applied to all individual glaciers of the SGI2016. GloGEM has been calibrated to glacier-specific observations of ice volume change between 2000 and 2019 (Hugonnet et al., 2021). For computational reasons, the model is discretized into $10 \mathrm{~m}$ elevation bands but results on area and thickness changes in individual bands are extrapolated to the same $10 \mathrm{mx} 10 \mathrm{~m}$ grid that is used in the analysis of potential glacier lakes (cf. Sec. 3.1). The model is forced with gridded monthly temperature and precipitation data from the ERA-5 re-analysis (Hersbach et al., 2020) for the past, and with results from a total of 56 different Global Circulation Model (GCM) runs or the future and until the end of the $21^{\text {st }}$ century. The 56 runs stem from 13 different GCMs used in the sixth phase of the

155 Coupled Climate Model Intercomparison Project (CMIP6; Eyring et al., 2016) and are based on five different Shared Socio-economic Pathways (SSPs; Meinshausen et al., 2020; note that for SSP119 only 4 GCM runs are available). The latter describe future climate forcing due to both different greenhouse gas emissions and political environment. Whereas SSP119 and SSP126 refer to low-emission scenarios assuming global $\mathrm{CO}_{2}$-neutrality by the second half of the century, SSP585 is a high-emission scenario with limited efforts to mitigate climate change. In the following, results of the intermediate scenario SSP245 is used in most analyses to illustrate the results.

For each of the 56 climate model chains considered and for each potential glacier lake, we compute the year when $>0 \%$, $25 \%, 50 \%, 75 \%$ and $100 \%$ of the lake area become ice-free, as well as the yearly lake volume for the area that has become 
https://doi.org/10.5194/esurf-2022-12

Preprint. Discussion started: 1 March 2022

(c) Author(s) 2022. CC BY 4.0 License.

ice-free. In the following, results are aggregated by SSPs, providing (i) the average year of lake formation, (ii) a lake volume time series for each SSP, as well as (iii) an uncertainty range given by the spread in the results obtained from different GCMs forced with the same SSP.

\subsection{Lake sedimentation}

In order to obtain a first-order estimate for the time required to fill overdeepenings becoming ice-free with sediments, we propose a simple approach that is tightly connected to the GloGEM results. Accounting for the spatio-temporal dynamics of sedimentation of new glacier lakes is crucial as (1) many - especially smaller - overdeepenings will be sedimented a few years after their formation (e.g. Mölg et al., 2021), and (2) erosion and sediment-transport rates in glacial environments are known to be extreme (for compilations of such rates, see Hinderer et al., 2013 or Carrivick and Tweed, 2021). In this respect, glacial overdeepenings represent important sediment traps (e.g. Geilhausen et al., 2013; Bogen et al., 2015), and the connectivity of the fluvial system emerging after glacier retreated must be considered since lower-lying areas might be deprived of sediment input once new traps come into existence above (Micheletti and Lane, 2016; Lane et al., 2017). A detailed description of the sediment processes that affect deglacierizing areas is out of reach for regional to global-scale glacier models, and considerable simplifications are necessary. The approach described below attempts to quantify the most relevant drivers of sediment yields into proglacial basins, and to capture the corresponding spatio-temporal dynamics.

We parameterize the sediment volume transported into a glacial lake via (i) the sediment load per unit volume of water $\left(c_{\text {sed,in }}\right.$, in $\mathrm{kg} \mathrm{m}^{-3}$ ), and (ii) the glacial runoff (in $\mathrm{m}^{3} \mathrm{~s}^{-1}$ ) originating from the catchment area above the considered lake in month $m\left(Q_{m, \text { top }}\right)$ according to GloGEM (Huss and Hock, 2018). Furthermore, we consider the typically much lower sediment concentrations in water flowing out of a proglacial lake ( $\left.c_{\text {sed,out }}\right)$, i.e. after sedimentation (e.g. Bogen et al., 2015). Monthly sediment volumes deposited in a proglacial overdeepening are thus computed as

$$
V_{\text {sediment }, m}=\frac{C_{\text {sed,in }}-C_{\text {sed,out }}}{\rho_{\text {sed }}} \cdot Q_{m, \text { top }},
$$

where $\rho_{\text {sed }}$ is the estimated density of deposited sediment, here set to $2200 \mathrm{~kg} \mathrm{~m}^{-3}$ (Hinderer et al., 2013). For simplicity, we assume sediment output from the lake $c_{\text {sed,out }}$ to remain constant in time, and set it to $0.05 \mathrm{~kg} \mathrm{~m}^{-3}$ based on literature values

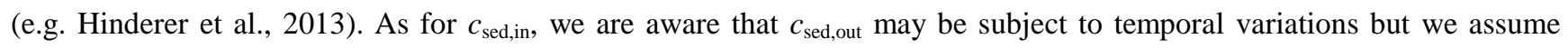
these to be dampened by the lakes and to be relatively small in absolute terms. In our approach, $c_{\text {sed,in }}$ will be subject to major variations depending on the sediment sinks above the considered lake, as well as due to the erodibility of the basin which is influenced by factors such as slope, recently exposed proglacial area, and the height of the headwall (Ballantyne, 2002; Benn and Evans, 2010; Costa et al., 2018; Antoniazza and Lane., 2021; Carrivick and Tweed, 2021). In order to estimate $c_{\text {sed,in, }}$, we parameterize three main processes: (1) subglacial abrasion, (2) the increase in deglacierized area, and (3) 
https://doi.org/10.5194/esurf-2022-12

Preprint. Discussion started: 1 March 2022

(c) Author(s) 2022. CC BY 4.0 License.

glacial and periglacial erosion. In the following we describe how these processes are quantified individually, noting that our approach is highly parameterized and simple.

(1) Subglacial abrasion scales with glacier flow speed (e.g. Herman et al., 2015), and is parameterized as a non-dimensional index $i_{\text {abrasion }}$ depending on instantaneous mean glacier thickness $h_{\text {mean }}$ and mean glacier slope $\alpha_{\text {mean }}$ :

$$
i_{\text {abrasion }}=\frac{h_{\text {mean }} \cdot \alpha_{\text {mean }}}{h_{\text {crit }} \cdot \alpha_{\text {crit }}},
$$

where $h_{\text {crit }}$ and $\alpha_{\text {crit }}$ are critical values for mean thickness and slope that correspond to an average Swiss glacier (e.g. Linsbauer et al., 2021). For thick or steep glaciers, $c_{\text {sed,in }}$ is thus increased relative to the reference value, and vice versa for thin or flat glaciers. No contribution from this process occurs once the glacier has completely disappeared.

(2) The deglacierized area is known to be a major erosion source due to exposed unconsolidated sediment (e.g. Delaney et al., 2018b). Analogously to (1), we parameterize this effect with an index $i_{\text {proglacial }}$ dependent on the area $A_{\text {proglacial }}$ exposed by glacier retreat since the beginning of the simulations, its average age $t_{\text {proglacial, }}$, and its average slope $\alpha_{\text {proglacial }}$ :

$$
i_{\text {proglacial }}=\frac{t_{\text {crit }}}{t_{\text {proglacial }}} \cdot \frac{\alpha_{\text {proglacial }}}{\alpha_{\text {crit }}} \cdot \frac{A_{\text {proglacial }}}{A_{\text {basin }}}
$$

Here, $t_{\text {crit }}$ is the full time interval of the simulations (i.e. 100 years, from 2000 to 2100), and $A_{\text {basin }}$ is the total area of the basin. Thus, a large, steep and recently deglacierized proglacial area will result in higher $c_{\text {sed,in }}$ than a small, flat, or longestablished one. Geometrical parameters for the shape and the age of the proglacial area are extracted from GloGEM results at annual time steps.

(3) Glacial and periglacial erosion is most powerful in headwalls (MacGregor et al., 2009). For each glacier, we compute the area and the average slope of the headwall, here defined as the non-glacierized area above the glacier's median elevation lying within the glacier's hydrological catchment (the latter is defined based on the DEM extending beyond the presently glacierized surfaces). The index $i_{\text {headwall }}$ depends on both the headwall area $A_{\text {headwall }}$ relative to the original glacier area and the mean slope of the headwall $\alpha_{\text {headwall }}$ :

$$
i_{\text {headwall }}=C_{\text {headwall }} \cdot \frac{A_{\text {headwall }}}{A_{\text {basin }}} \cdot\left(\frac{\alpha_{\text {headwall }}}{\alpha_{\text {crit }}}\right)^{2},
$$

where $c_{\text {headwall }}$ is a dimensionless scaling parameter empirically set to 2.5. The square in the right-most term of the equation is meant to qualitatively capture the exponential effect that headwall slope has on the erosion potential, although further studies would need to confirm this relation quantitatively. Finally, the indices for the three considered factors are averaged to yield $c_{\text {sed,in }}$ :

$$
C_{\text {sed }, \text { in }}=C_{\text {sed,in ref. }} \cdot \frac{\left(i_{\text {abrasion }}+i_{\text {proglacial }}+i_{\text {headwall }}\right)}{3},
$$


https://doi.org/10.5194/esurf-2022-12

Preprint. Discussion started: 1 March 2022

(c) Author(s) 2022. CC BY 4.0 License.

where $c_{\text {sed,in ref. }}=0.50 \mathrm{~kg} \mathrm{~m}^{-3}$ is a reference sediment concentration in proglacial runoff for any basin, the value being determined based on long-term observations in proglacial streams in the Swiss Alps (e.g. Hinderer et al., 2013; Delaney et al., 2018a). As the three indices $i_{\text {abrasion, }} i_{\text {proglacial }}$ and $i_{\text {headwall }}$ are annually updated based on the basin's current morphology, also $c_{\text {sed,in }}$ will mirror long-term variations in the basin's characteristics. In particular, $c_{\text {sed,in }}$ will respond to changes in glacier ice extent, the condition of the proglacial area, and the extent of the headwall. Albeit empirical, the approach allows for capturing both the high variability in erodibility of different glacier catchments, as well as the temporal dynamics of sediment yield in the transition from glacierized to ice-free basins.

In the case that multiple potential glacier lakes are exposed at the same time, we assume all of them to be directly linked with each other, and to transfer water and sediments from the higher lakes to lower ones. Two-dimensional aspects of connectivity are neglected for simplicity. The topmost exposed proglacial overdeepening receives a sediment yield corresponding to Eq. (1), computed using all runoff originating from above the respective elevation. Lower-lying potential lakes, however, are only fed by sediment yields computed based on runoff from the elevation interval up to the next higher potential lake, which typically results in much smaller sediment input. For each potential lake, the volume that is still free from sediments is annually updated, and as soon as it is completely sedimented, it is no longer considered as a sediment sink. This can then cause the sediment yields to rise again in lower-lying lakes.

\subsection{Uncertainties}

Our results are affected by various uncertainties, including uncertainties in the lakes’ morphology (i.e. location, total area, and total volume) and temporal evolution (i.e. year of formation and rate of sedimentation). The following paragraphs describe how each of these uncertainties is estimated.

\subsubsection{Uncertainty in lake location and area}

The location and areal extent of the individual, potential lakes are determined by the subglacial topography. This means that in general, the number of lakes, the lake extents, as well as the lake locations computed on the basis of the subglacial topography generated with GlaTE (cf. Sec. 2) might be different from the ones computed by using the subglacial topography generated with ITVEO. Similar is true when comparing the lakes computed on the basis of the mean bedrock topography with either of the results from GlaTE or ITVEO. Because of these differences, it is not possible to establish a one-to-one relation between lakes generated on the basis of the individual bedrock topographies and we thus estimate the uncertainty in lake extents by aggregating the results at the level of individual glaciers. More specifically, we compute (1) the total area of lakes obtained for a given glacier by using the GlaTE bedrock topography and (2) the total area of lakes obtained for the same glacier by using the ITVEO topography, and use the relative difference of these totals ( $\Sigma A_{\text {GlaTE }}$ and $\Sigma A_{I T V E O}$, respectively) as an estimate for the relative uncertainty $\left(\sigma_{A}\right)$ of each lake with area $A$, i.e. 


$$
\frac{\sigma_{A}}{A}=\frac{\left|\sum A_{G l a T E}-\sum A_{I T V E O}\right|}{\operatorname{avg}\left(\sum A_{\text {GlaTE }}, \sum A_{\text {ITVEO }}\right)} .
$$

This uncertainty is assumed to apply to every lake, notably also to the lake estimated with the mean bedrock topography. We also assume the individual lake extents to be independent, meaning that the uncertainty for the total area of a given set of lakes is computed by adding the uncertainty of individual lakes in quadrature.

\subsubsection{Uncertainty in lake volume:}

250 Also the uncertainty in lake volume is controlled by the uncertainty in the subglacial topography. The dataset by Grab et al. (2021) provides information about the local uncertainty of the bedrock elevations (z), and does so by providing an upper and a lower bound ( $z^{+}$and $z^{-}$, respectively) for the corresponding values. These bounds are based on an analysis of the used interpolation methods, the uncertainty in the GPR profiles, and the uncertainties of the surface DEM. In general, the uncertainty in the subglacial topography increases with the distance to the closest GPR measurement (for details, refer to

255 Grab et al., 2021).

Since the total volume of each lake $(V)$ is given by integration of all lake depths within the lake's area $(A)$, and since the lake depth information is provided on a grid with grid-cell area $A_{\text {cell, }}$, we use the uncertainty-estimates provided by Grab et al. (2021) to compute an upper and a lower bound for the lake's total volume ( $V^{+}$and $V$, respectively):

$$
\left\{\begin{array}{l}
V^{+}=V+A_{\text {cell }} \cdot \sum\left(z^{+}-z\right) \\
V^{-}=V+A_{\text {cell }} \cdot \sum\left(z^{-}-z\right)
\end{array} .\right.
$$

In the equation, $V$ is the lake volume computed by using the mean bedrock topography, and the sums are performed over all grid-cells that lie within the area of the given lake. Note that, by definition, $z^{+} \geq z \geq z^{-}$(and thus $V^{+} \geq V^{-}$), and that in general $\left|z^{+}-z\right| \neq\left|z^{-}-z\right|$. The latter leads to an asymmetric confidence interval around $V$.

Since we don't expect the results by Grab et al. (2021) to be systematically biased towards either $z^{+}$or $z^{-}$, we treat the uncertainties in different lake volumes as independent and thus sum the estimated uncertainties in quadrature.

\subsubsection{Uncertainty in the year of lake formation}

265 We estimate the uncertainty in the year of lake formation as the standard deviation of the 13 different years of lake formation resulting from the 13 GCMs considered for each SSP. The year of lake formation will in fact also be affected by other uncertainties such as the subglacial topography (e.g. Farinotti et al., 2017), as well as structural uncertainties in the glacier model itself (e.g. Huss and Hock, 2015). However, several studies have shown that climate model uncertainty largely dominates over glacier model uncertainty (e.g. Marzeion et al., 2018, 2020). We therefore refrain from propagating uncertainties from subglacial topography and the glacier model through all climate scenarios.

\subsubsection{Uncertainty in sedimentation rates}


https://doi.org/10.5194/esurf-2022-12

Preprint. Discussion started: 1 March 2022

(c) Author(s) 2022. CC BY 4.0 License.

Estimating the uncertainty in sedimentation rates is highly challenging as only few data are available for direct benchmarking. We account for uncertainties in our first-order estimates in the same way as for the year of lake formation, i.e. by determining the standard deviation of the results provided by the 13 GCMs considered for each SSP. We deem it likely that actual uncertainties are larger, especially when considering that (i) the underlying processes are only described by highly simplified parameterizations, and (ii) systematic uncertainties due to the chosen model parameters come into play as well. We argue that our simplified approach is defensible as our present understanding does not allow for providing a more complete uncertainty assessment.

\section{Results}

\subsection{Potential future lakes}

In total, we detected 683 potential lakes with an area larger than 5,000 $\mathrm{m}^{2}$ and a maximum depth of at least $5 \mathrm{~m}(3,600$ potential lakes are detected without imposing any criteria on size). They extend over a total area of $45.2 \pm 9.3 \mathrm{~km}^{2}$ (Fig. $2 \mathrm{~A}$ ), which is about $4.7 \%$ of the presently glacierized area in Switzerland. The total potential lake volume, i.e. the total volume of all detected potential lakes, is $1.16[1.05,1.32] \mathrm{km}^{3}$ (Fig. 2B; numbers provide the mean estimate together with a 95\% confidence interval). Whilst the average depth is of only 25.7 [22.2, 29.2] m (Fig. 2C), the maximal depth reaches as much as $\sim 330 \mathrm{~m}$. This extraordinary depth is detected for the largest potential lake, which is situated below Konkordiaplatz, i.e. at the confluence zone of the individual branches of Grosser Aletschgletscher (Fig. 1B). The average elevation of the detected potential lakes is $2776 \mathrm{~m}$ a.s.l., although individual lakes are found as high up as $\sim 4300 \mathrm{~m}$ a.s.l. (Fig. 2D), below Colle Gnifetti, Gornergletscher. The largest fraction of the identified, potential total volume is contained within a reasonably small number of large depressions: the 11 largest potential lakes, for example, contribute a total volume of $0.54[0.45,0.67] \mathrm{km}^{3}$, corresponding to $46 \%$ of the total (Fig. 2B).

To obtain a regional picture, we aggregated the potential lakes among the four main river catchments of Switzerland (Fig. 1). The region with the highest number of potential glacier lakes (447) is the Rhone basin, where their volume corresponds to $2.2 \%$ of the total glacier volume at present. In the Rhine and Inn catchments, 185 and 26 potential lakes are found, respectively. The total lake volume in these catchments corresponds to $1.5 \%$ (Rhine) and $1.4 \%$ (Inn) of the presentday glacier volume. The region with the lowest number of potential glacier lakes (24) is the Po catchment, where the total lake volume is equivalent to $0.6 \%$ of today's glacier volume.

In general, the size of the potential lakes is related to the size of the glacier, meaning that the largest potential lakes are also found beneath the largest glaciers. Our results indicate that the four glaciers with the highest potential lake volume might give rise to up to 117 new lakes, accounting for 53\% of the anticipated total volume in Switzerland. The five largest potential lakes of the Swiss Alps are characterised in Table 1. To first instance, the correlation between lake size and 
https://doi.org/10.5194/esurf-2022-12

Preprint. Discussion started: 1 March 2022

(c) Author(s) 2022. CC BY 4.0 License.

glacier extent can be attributed by the fact that larger glaciers have more erosive power, and thus can produce larger overdeepenings (Iken \& Bindschadler, 1986).

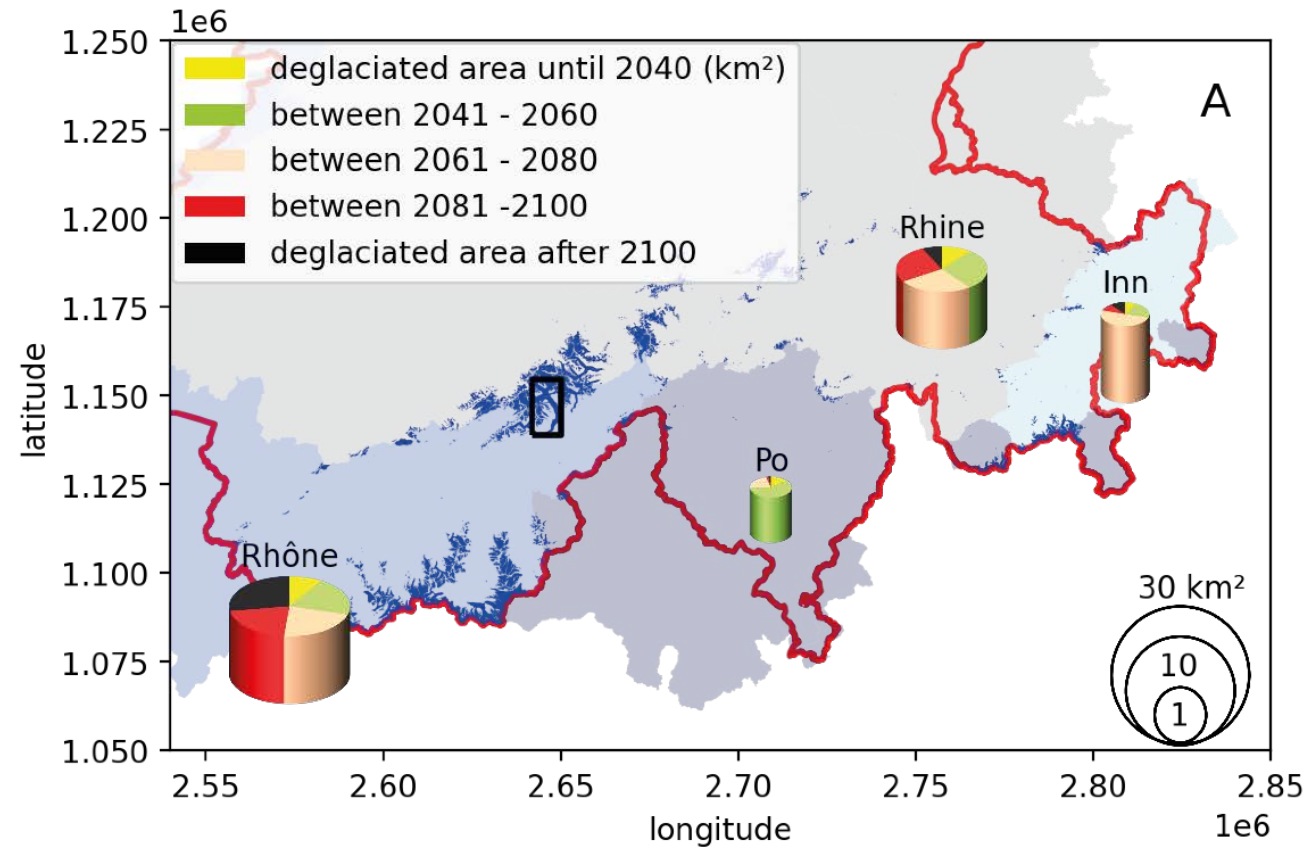

305

Figure 1 (A) Map of Switzerland showing the four main river basins (background colours) used for aggregating the results. Glacier extents according to the SGI2016 (Linsbauer et al., 2021) are shown in dark blue. For each catchment, the temporal evolution of the total area of the detected potential glacier lakes is indicated (pie chart area on logarithmic scale, legend at bottom right). The results are given in 20-year intervals (see legend at top left) and correspond to the simulations driven by the median scenario SSP245. Sedimentation is neglected in this graph. The height of the pies indicates the mean depth of the potential lakes within a given catchment. The black box shows the area enlarged in panel B. (B) Map of the lower part of Grosser Aletschgletscher, illustrating the morphology of potential glacier lakes. Lakes are contoured in red with depths given by the reddish colours. The SGI 2016 glacier extent (blueish background) is given together with a relief of the swissALTI3D surface DEM and the subglacial topography (grey shading). 
https://doi.org/10.5194/esurf-2022-12

Preprint. Discussion started: 1 March 2022

(c) Author(s) 2022. CC BY 4.0 License.
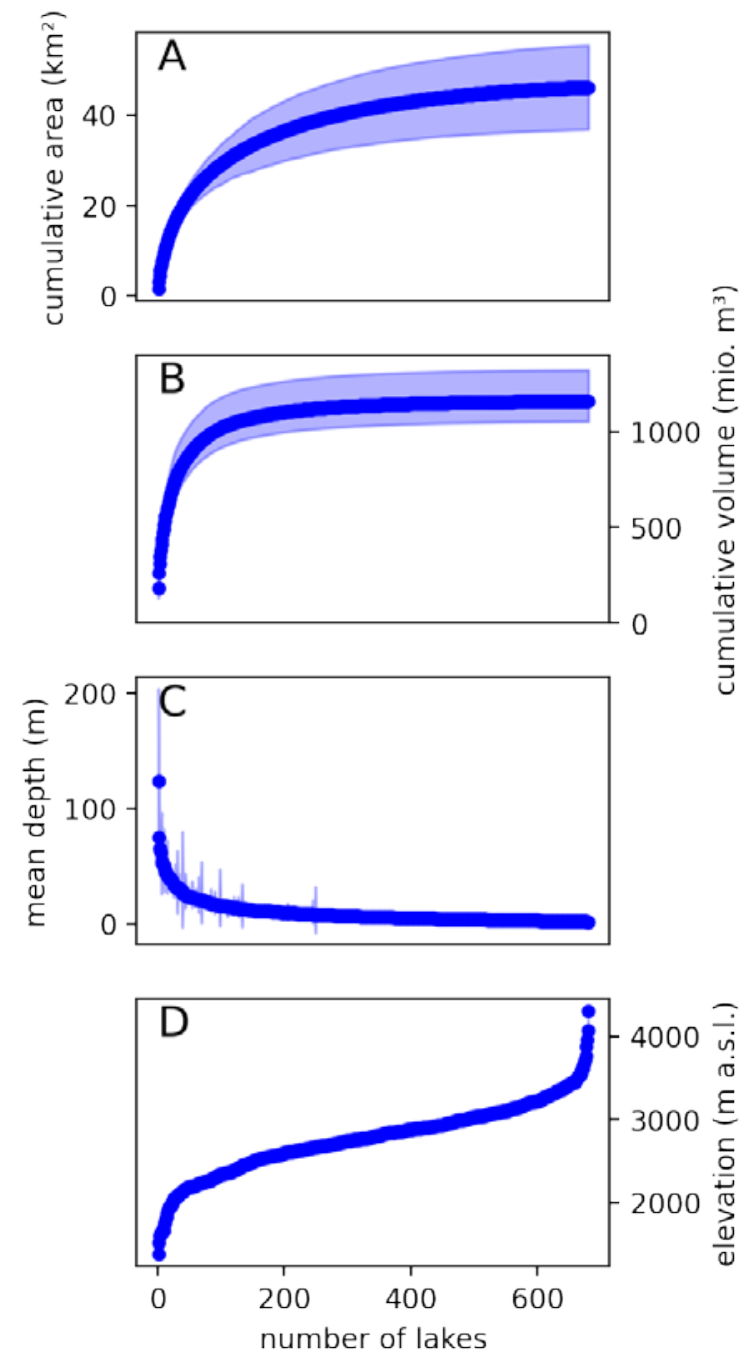

Figure 2 Cumulative area (A) and volume (B) of all potential lakes identified within the perimeter of the SGI2016 (Linsbauer et al., 2021). The cumulative uncertainty is given by the shaded bands. Distribution of (C) average depth and (D) elevation of the maximal lake level of all potential lakes. In panel $\mathbf{C}$, shaded bars show the uncertainties of each individual lakes whilst in panel $\mathbf{D}$ the uncertainty is too small to be seen ( $<80 \mathrm{~m}$ in all cases). 
https://doi.org/10.5194/esurf-2022-12

Preprint. Discussion started: 1 March 2022

(c) Author(s) 2022. CC BY 4.0 License.

Table 1 Overview of the five largest potential lakes. The lake volume expected to be ice free until 2050 and 2100 (neglecting sedimentation) is given for SSP245 and is expressed in \% of the potential total lake volume. Square brackets provide a confidence intervals for the given quantities (see Sec. 3.4.2). Note that two of the five potential lakes are anticipated for Grosser Aletschgletscher.

\begin{tabular}{l|cccccc}
\hline Glacier & Lake-ID & $\begin{array}{c}\text { Area } \\
\left(\mathrm{km}^{2}\right)\end{array}$ & $\begin{array}{c}\text { Elevation } \\
(\mathrm{m} \text { a.s.l. })\end{array}$ & $\begin{array}{c}\text { Pot. volume } \\
\left(\mathrm{mio.} \mathrm{m}^{3}\right)\end{array}$ & $\begin{array}{c}\text { Volume free } \\
\text { until } 2050(\%)\end{array}$ & $\begin{array}{c}\text { Volume free } \\
\text { until 2100 (\%) }\end{array}$ \\
\hline Gr. Aletschgletscher & B36-26-01 & $1.5 \pm 0.1$ & 2206 & $183[131,263]$ & $0[0,0]$ & $2[0,7]$ \\
Rhonegletscher & B43-03-01 & $1.1 \pm 0.1$ & 2566 & $82[53,137]$ & $0[0,0]$ & $74[4,100]$ \\
Gornergletscher & B56-07-01 & $1.7 \pm 0.1$ & 2187 & $46[15,98]$ & $34[3,72]$ & $95[58,100]$ \\
Gr. Aletschgletscher & B36-26-02 & $0.6 \pm 0.1$ & 1840 & $36[18,65]$ & $0[0,0]$ & $97[75,100]$ \\
Fieschergletscher & B40-07-01 & $0.7 \pm 0.2$ & 2809 & $32[16,61]$ & $0[0,0]$ & $6[0,17]$ \\
\hline
\end{tabular}

Table 2 Overview of the total potential lake volume anticipated to emerge by the years 2050 and 2100 when accounting for sedimentation (first two columns), the percentage of the total lake volume that might be lost because of sedimentation until 2100 (as \% of the potential volume), as well as numbers of potential lakes appearing (because of glacier retreat) and disappearing (because of sedimentation) until the year 2100 (last two columns).

\begin{tabular}{c|ccccc}
\hline $\begin{array}{c}\text { Climate } \\
\text { Scenario }\end{array}$ & $\begin{array}{c}\text { Pot. volume } \\
2050\left(\mathrm{~km}^{3}\right)\end{array}$ & $\begin{array}{c}\text { Pot. volume } \\
2100\left(\mathrm{~km}^{3}\right)\end{array}$ & $\begin{array}{c}\text { Sedimented } \\
\text { until } 2100 \\
(\%)\end{array}$ & $\begin{array}{c}\text { lakes appeared } \\
\text { by } 2100\end{array}$ & $\begin{array}{c}\text { lakes disappeared } \\
\text { by } 2100\end{array}$ \\
\hline SSP119 & $0.09[0.01,0.18]$ & $0.20[0.04,0.33]$ & $25 \pm 13$ & $381 \pm 140$ & $186 \pm 65$ \\
SSP126 & $0.10[0.03,0.18]$ & $0.35[0.12,0.49]$ & $21 \pm 7$ & $473 \pm 79$ & $222 \pm 37$ \\
SSP245 & $0.12[0.04,0.18]$ & $0.56[0.26,0.67]$ & $16 \pm 5$ & $570 \pm 61$ & $260 \pm 28$ \\
SSP370 & $0.13[0.04,0.22]$ & $0.82[0.41,1.01]$ & $13 \pm 3$ & $637 \pm 53$ & $277 \pm 27$ \\
SSP585 & $0.19[0.05,0.26]$ & $0.94[0.51,1.04]$ & $11 \pm 3$ & $655 \pm 40$ & $287 \pm 24$ \\
\hline
\end{tabular}


https://doi.org/10.5194/esurf-2022-12

Preprint. Discussion started: 1 March 2022

(c) Author(s) 2022. CC BY 4.0 License.

\subsection{Formation of glacier lakes and sedimentation}

Depending on the climate scenario, the total volume of potential glacier lakes that will be exposed until the end of this century can strongly vary (Table 2). Within the first half of this century, the projected glacier retreat and thus the formation of new glacier lakes is not particularly sensitive to the chosen climate scenarios (Fig. 3A), in contrast to the situation after 2050. SSP585, for example, shows a rapid formation of new lakes after 2050. This formation only decelerates towards the end of this century, when most glaciers will have vanished entirely. SSP245, instead, leads to an almost linear increase in the volume of potential new lakes, with the formation of additional $8.2 \pm 2.5$ mio. $\mathrm{m}^{3}$ every year between 2040 and 2100 . According to SSP126 and SSP119, some glaciers might even re-advance towards the end of this century thus filling some formerly deglacierized lakes with ice once again. This explains the stabilization of the newly emerging potential lake volume projected according to SSP119 (Fig. 3A). We find that between 380 (SSP119) and 655 (SSP585) new glacier lakes might form until 2100 (Table 2). This is between $\sim 30 \%$ and $\sim 65 \%$ of the number of new glacier lakes that have been formed in Switzerland since the Little Ice Age, i.e. in the past 170 years (Mölg et al., 2021). When accounting for sedimentation, we find that between 185 (SSP119) and 285 (SSP585) new proglacial lakes completely disappear again until 2100 due to infill. This corresponds to $49 \%$ and $44 \%$ of the new lakes, respectively, but relates to small overdeepenings with a rather limited potential volume.

The rate of formation of new glacier lakes differs within the four main river catchments used to aggregate the results (Fig. 1 and 3B). After 2040, the rate is approximatively constant in all catchments, the highest rates being anticipated for the Rhone and Rhine catchments (annual increase of potential lake volume of 6.82 and $2.65 \mathrm{mio} \mathrm{m}^{3}$ per year, respectively; Fig. 3B). In the Inn catchment, this rate slows down after 2070 since most glaciers are projected to have vanished by then. In the Po catchment, the same reason causes the potential glacier lake volume to remain virtually unchanged after ca. 2060, with only four potential lakes not having formed by then.

According to our results, sedimentation of new glacial lakes is an important process that has the potential to fill especially smaller bedrock overdeepenings. Depending on the climate scenario, we find that between 185 and 285 new lakes (i.e. slightly less than half of the total) will be completely re-filled with sediments by 2100 (Table 2). The total lake volume lost through this process varies between $32 \pm 13 \%$ for SSP119 and $11 \pm 2 \%$ for SSP585, the strong dependence on the climate scenario being caused by the different glacier extents. Indeed, climate scenarios anticipating less warming (e.g. SSP119) imply larger glacierized areas, and thus result in both the formation of fewer glacier lakes and generally higher sedimentation rates owing to the high erosive action of the glaciers themselves. The model results also indicate that large potential lakes may only lose a small percentage of their volume through sedimentation, whilst smaller sediment sinks can be filled within years after their appearance.

Our simple model for catchment erosion and the provision of sediment to new glacier lakes (see Section 3.3) shows complex spatio-temporal dynamics. At the scale of the entire Swiss Alps, we expect sedimentation input into newly formed 
https://doi.org/10.5194/esurf-2022-12

Preprint. Discussion started: 1 March 2022

(c) Author(s) 2022. CC BY 4.0 License.

lakes to increase until about 2050 (with a range of \pm 5 years depending on the scenario) and then to decrease towards the end of the century (Fig. 4A). This is explained by the fast exposure of vast proglacial areas with erodible unconsolidated sediments that are assumed to stabilize with increasing age. At the same time, the decreasing thickness of glaciers reduces their potential for bedrock abrasion, with a corresponding reduction of the long-term sediment yield. Furthermore, sedimentation rates in the newly exposed areas also decrease in the long term as smaller lakes, acting as sediment sinks, will fill up and not retain sediments any longer. Highest sedimentation rates, of up to $1.9 \pm 0.5 \mathrm{mio} \mathrm{m}^{3} \mathrm{yr}^{-1}$, are expected for the high-emission scenario SSP585, while rates peak earliest for SSP119 and reach $1.2 \pm 0.5 \mathrm{mio} \mathrm{m}^{3} \mathrm{yr}^{-1}$. When transiently accounting for sediment input, the number of lakes increases throughout the $21^{\text {st }}$ century for all scenarios (Fig. 4B), but only reaches $40-50 \%$ of the potential total (see also Table 2). While intermediate scenarios show a continuous growth in lake number, a stabilization is modelled both for the lowest and highest emission scenarios. The reasons are contrasting: For SSP585, almost all potential lakes are exposed but especially smaller ones are sediment-filled towards the end of the century. For SSP119 in contrast, glaciers stabilize with climate beyond about 2080 (e.g. Compagno et al., 2021) thus not exposing further lakes. The share of potential new lake volume that is filled with sediment is an important measure to assess the evolution of future lakes. While values range between $11 \%$ and $25 \%$ for the end of the century, the share of already-exposed lakes that fill with sediments again shows a peak at about 40\% around 2030 (independently of the SSP), and decreases afterwards (Fig. 4C). We explain this by the lagged retreat of glacier termini, which first only exposes relatively small lakes that are readily filled with sediments again. When the rate of retreat accelerates towards 2050, and more and larger potential lakes are exposed, the still rising sediment input (Fig. 4A) is more efficiently stored.

The complexity of the temporal sedimentation dynamics is best illustrated at the scale of an individual new glacier lake: Figure 5 shows the volume evolution of the large lake at the snout of Gornergletscher. In a climate scenario implying high emissions (SSP585), the lake is expected to first appear around the year 2025, to experience fast deglaciation especially after 2040, and to be completely ice-free by about 2060 (Fig. 5A). Whereas modelled overall basin erosion rates show a increase to about $0.9 \mathrm{~mm} \mathrm{a}^{-1}$ by 2050 and a subsequent decrease to about $0.6 \mathrm{~mm} \mathrm{a}^{-1}$ (Fig. 5B), actual sedimentation rates of the lake also show strong short-term variability. This is explained by (partly) intermittent exposure of smaller lakes upstream of the considered lake. Indeed, the former act as efficient sediment sinks, and strongly reduce sediment provision 390 to the areas downstream. Whilst by 2100 only ca. 5\% of the considered lake volume is expected to have re-filled by sediments, sedimentation almost keeps pace with the rate of lake volume growth until 2040, i.e. in the phase in which the lake volume is still limited. This suggests that accounting for sedimentation processes is especially important in the early stages of new glacier lake formation. 

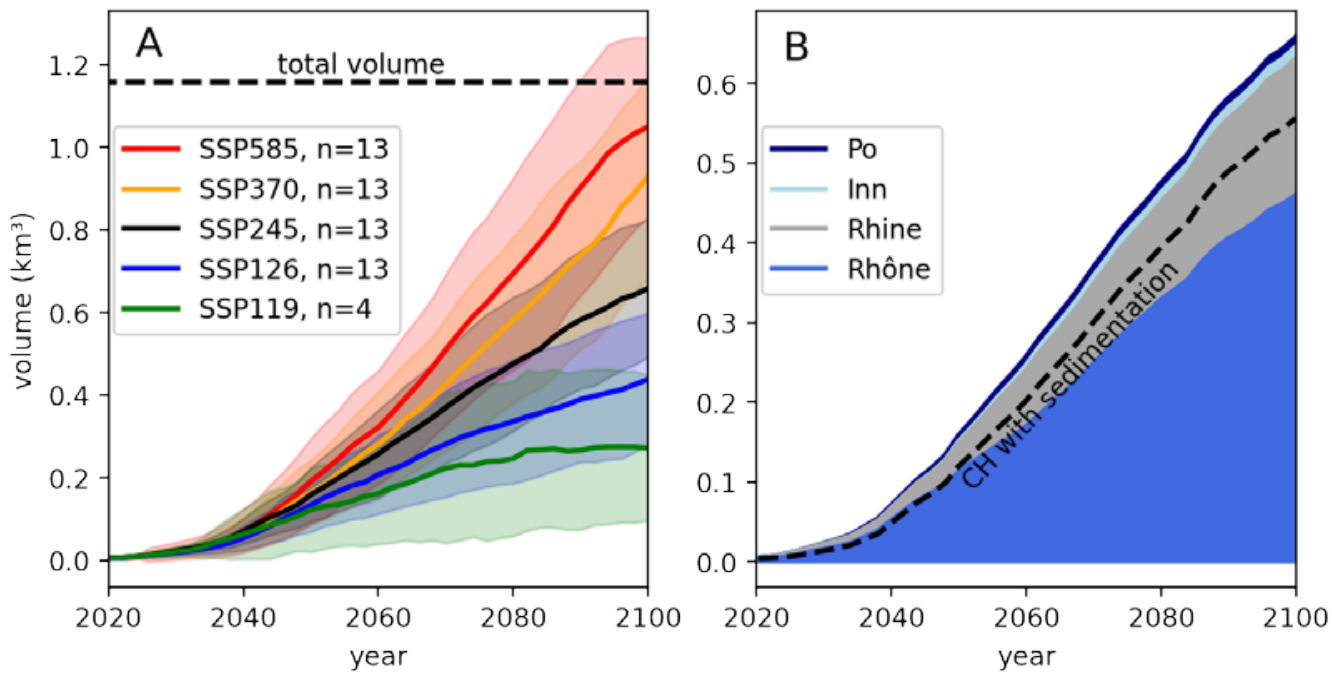

Figure 3 (A) Temporal evolution of the total potential glacier lake volume without sedimentation. The total possible volume (i.e. the maximal lake volume that would be realised if all glaciers were to vanish entirely) is indicated with the dashed line (95\% confidence interval [1.05, 1.32], not shown). Five different climate scenarios (SSPs) are distinguished. The shaded regions depict the spread between the results obtained with individual climate model chains. (B) Temporal evolution of the total potential glacier lake volume without sedimentation, aggregated for the four main river catchments in Switzerland (see Fig. 1). The results refer to the median scenario SSP245. The dashed line shows the total volume for all four catchments when taking the modelled sediment input into account. 
https://doi.org/10.5194/esurf-2022-12
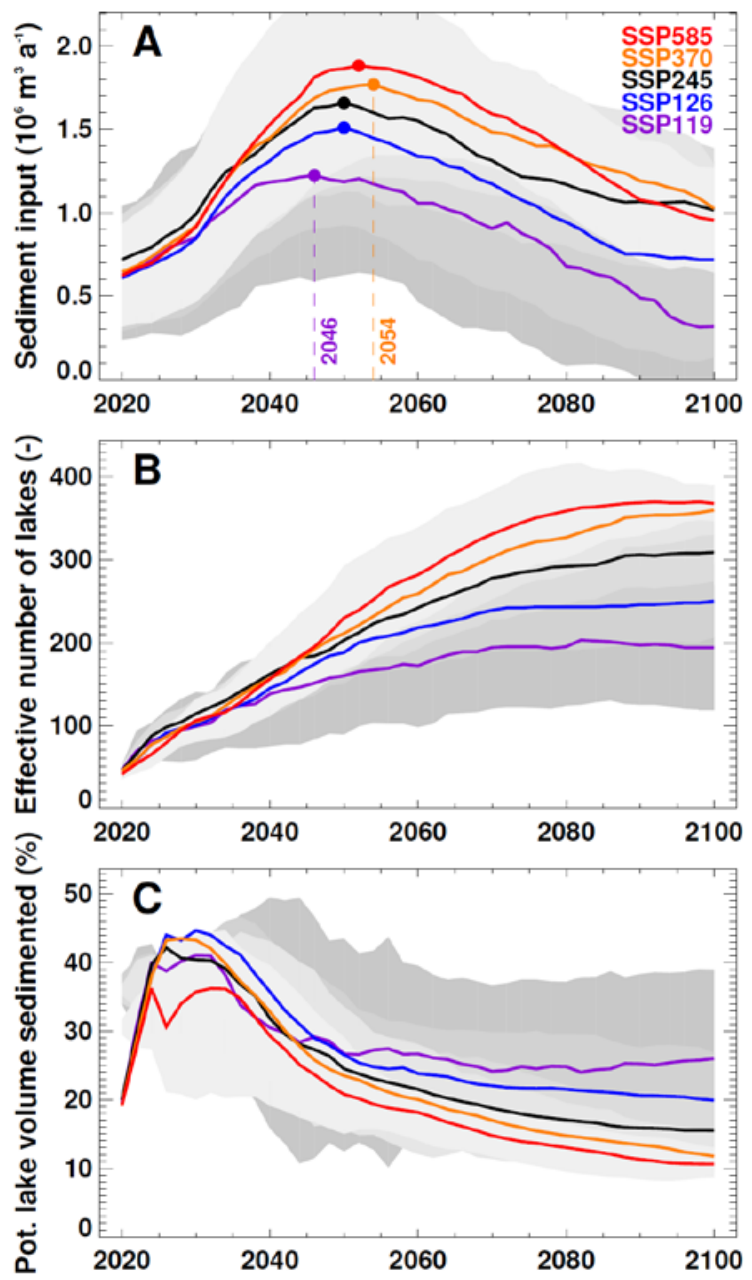

Figure 4 (A) Temporal evolution of modelled annual sediment input into new potential lakes formed due to glacier retreat after 2016 (onset of glacier evolution modelling) for all SSPs. Lines are smoothed with a 11-year running mean and represent the average of all 13 GCMs for a given SSP. Dots indicate the timing of the maximum sediment input into lakes. (B) Evolution of the effective number of new potential lakes, i.e. accounting for lake basins being completely sedimentfilled. (C) Share of potentially available lake volume throughout the 21st century being sedimented for the respective scenario. 
https://doi.org/10.5194/esurf-2022-12

Preprint. Discussion started: 1 March 2022

(c) Author(s) 2022. CC BY 4.0 License.

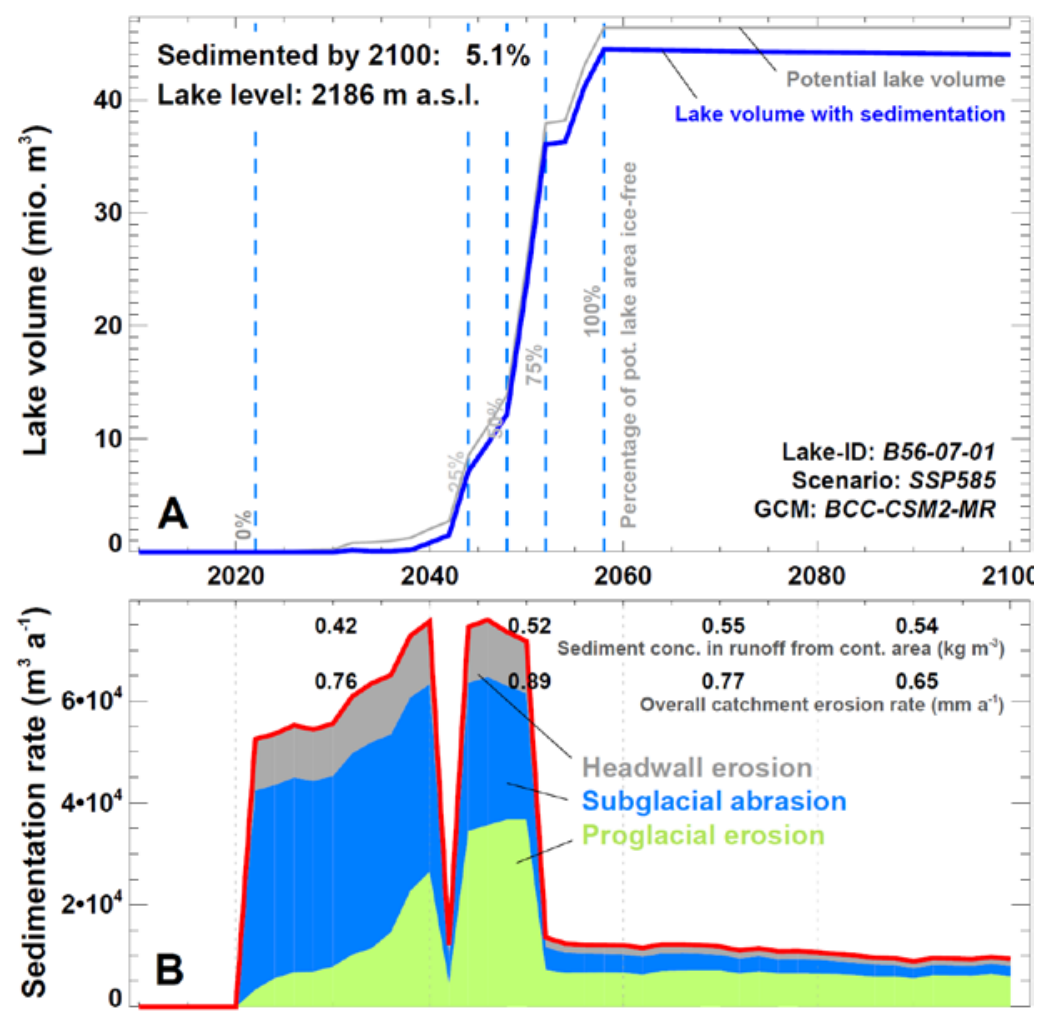

Figure 5 Temporal dynamics of lake volume growth and modelled sedimentation for the example of Gornergletscher (SGIID B56-07), harbouring the third-largest new glacier lake in Switzerland (cf. Table 1). Results refer to a selected GCM amid the climate scenario SSP585. (A) Lake volume evolution when neglecting (grey) or accounting for (blue) sedimentation. Percentages of exposed potential maximum lake area over time are shown (grey vertical numbers). (B) Modelled lake sedimentation rate, including the partitioning of the three considered sediment sources (cf. Section 3.3). The strong temporal variations are due to the appearance and re-filling of smaller glacier lakes located above the considered lake. Numbers in the upper part of the panel show (i) sediment concentrations in the runoff from the catchment area contributing to the lake at a given point in time, and (ii) modelled catchment erosion rates. The numbers are evaluated over 20-year time steps. 
https://doi.org/10.5194/esurf-2022-12

Preprint. Discussion started: 1 March 2022

(c) Author(s) 2022. CC BY 4.0 License.

\section{Discussion}

\subsection{The significance of new glacier lakes}

With close to 700 detected overdeepenings, the number of potential new glacier lakes in the Swiss Alps is significant. Albeit in terms of area and volume a relatively small share of lakes determines the totals (the largest 60 lakes account for $50 \%$ of the total area and $80 \%$ of the total volume, respectively; Fig. 1), this high number of emerging new lakes is set to change the appearance of the Alpine landscape - together with glacier retreat, which causes the emergence of these lakes in first place. A number of impacts can be anticipated from that, including the dynamics of the affected periglacial ecosystems, the potential anthropogenic use of the newly emerging lakes (e.g. for recreational use, water management purposes, or hydropower production), or the change in natural hazard potential as significant water masses come to lie in areas surrounded by steep topography and thus prone to gravitational mass movements such as rockfalls, avalanches, or even landslides. An in-depth analysis of the possible implications of newly emerging glacier lakes had be conducted in the frame of the Swiss National Research Programme 61 (NELAK, 2013) and it is beyond the scope of our analysis to summarize the findings here (for such a summary, refer to Haeberli et al., 2016). What our results show, however, is that part of this evolution is set to take place in any case, i.e. independently of the climate evolution of the next few decades. Indeed, as illustrated by Figure 3a for example, the temporal evolution of the emerging new lakes is virtually independent of the chosen climate scenario until ca. 2050. This is congruent with the anticipated glacier evolution in the Alps (e.g. Zekollari et al, 2019; Compagno et al., 2021) and is directly related to the glacier’s response time (Zekollari et al., 2020), i.e. the time required by glaciers to adapt their geometry to given climate conditions. In practice, this means that some $\sim 200$ potential new lakes are expected to emerge until 2050 in any case (average of all climate scenarios and climate model), whilst for the end of the century, the number lies between $\sim 240$ and 700 , depending on climate scenario and climate model realization (Table 2).

This large number of potential new lakes calls for a reflection about their future role and embedding. Whilst it might be anticipated that the large majority of potential new lakes will not trigger major debates and will naturally become part of the newly emerging landscapes, the situation could be different for some of the larger lakes. Here, the potential for conflicting interests can be seen, spanning from a strict preservation of their state due to their importance in terms of emerging natural habitats, to the exploitation for commercial use. Recent debates around this topic - mostly happening in the context of artificial reservoirs rather than natural lakes (e.g. Kellner, 2019; Kellner and Brunner, 2021; Kellner, 2021) have focused on the potentials for multipurpose usage, i.e. the potential of a given lake to satisfy different needs. Such needs range from the generation of hydroelectricity (e.g. Ehrbar et al., 2018), over the alleviation of water scarcity (e.g. Brunner et al., 2019), to the management in terms of flood prevention (e.g. Volpi et al., 2018) but are most often centred on anthropogenic interests. It seems desirable to extend these considerations to aspects that are more difficult to quantify in terms of economic value, notably including the ecosystem services provided by lakes (e.g. IPBES, 2019) and their role in 
https://doi.org/10.5194/esurf-2022-12

Preprint. Discussion started: 1 March 2022

(c) Author(s) 2022. CC BY 4.0 License.

the colonization of areas becoming ice free. Whether such considerations will gain momentum remains to be seen, but seem important in light of the scale of the changes to come.

\subsection{Actual lake formation and sedimentation}

In the presentation of our results, we stressed the wording "potential glacier lakes". This is to indicate that even for overdeepenings that are detected through GPR data with confidence, a considerable uncertainty remains about whether a lake will actually form. The actual formation can indeed be impeded by the local topography or geology. On the one hand, narrow outlet channels, which can neither be resolved by the GPR measurements nor be anticipated with the used ice thickness estimation approaches, can be sufficient for preventing a given glacier lake to form at all. On the other hand, overdeepenings eroded into porous or fissured bedrock might never fill with water because of leakage through the underlying rock. In their recent study, Mölg et al. (2021) determined that only about $40 \%$ of the area contained within overdeepenings that have been exposed by glacier retreat since the Little Ice Age actually filled with water to form a glacier lake. If this is assumed to be a characteristic value, it would mean that about $27 \pm 6 \mathrm{~km}^{2}$ of the identified potential future lake area $\left(45 \pm 9 \mathrm{~km}^{2}\right.$ in total) will never give rise to an actual lake.

A further process that might hamper actual lake formation is the re-filling with sediment. Our study is the first that attempts to capture this, and does so by using a simple approach that takes into account relevant processes, as well as their spatiotemporal changes. Although more process understanding is needed to increase the reliability of the related results, our assessment clearly suggests that sedimentation of new proglacial lakes in bedrock overdeepenings can be important, especially for small lakes in the first years after their formation. At the scale of the entire Swiss Alps, our model indicates that - depending on the climate scenario - between $11 \%$ and $32 \%$ of the potential new lake volume might be filled with sediments by 2100 , with higher relative sedimentation for low-emission scenarios. Although other factors, such as the actual volume of overdeepenings and whether they will actually fill with water (see above), are likely more important, it is clear that sediment input into new proglacial lakes will systematically reduce their volumes. Neglecting this effect thus results in an overestimate for the volume of potential future glacier lakes. Our approach shows complex spatio-temporal dynamics of the sediment input (Fig. 5) and captures effects such as the erodibility of sediments in the upstream catchment, the transport of fine-grained materials by water runoff, as well as the dependence on upstream sediment sinks given by other glacier lakes. Our model has to be understood as a first-order approach to characterize these dynamics, and recognize the weak validation of our approach. The problem here is that a validation at the scale of the Swiss Alps is almost impossible, given that only few data - mostly referring to individual and small basins - are available. Together with the realization that sediment fluxes from high mountain areas have significantly increased over the past decades (Li et al., 2021), our results might be a motivation to enhance our understanding of the related processes, thus spurring further studies in this domain. 
https://doi.org/10.5194/esurf-2022-12

Preprint. Discussion started: 1 March 2022

(c) Author(s) 2022. CC BY 4.0 License.

\subsection{Robustness of detected potential lakes}

Despite the unusually comprehensive set of GPR data available to determine the location and size of the potential future lakes, our results are critically dependent on the methods used to infer the subglacial topography in glacier areas that are not covered by the direct measurements. In this respect, we assess the robustness of our estimates by comparing the results obtained when using the two independent methods used by Grab et al. (2021), i.e. GlaTE and ITVEO. When applying the same thresholds for the detection of potential lakes as used for the mean bedrock topography (i.e. maximal lake depth $>5 \mathrm{~m}$ and lake area $>5,000 \mathrm{~m}^{2}$ ), ITVEO detects 973 lakes and GlaTE 725 (Fig. 5A and B). This is a significantly larger number when compared to the 683 potential lakes detected when using the mean bedrock topography (cf. Sec. 4) and indicates that for the latter, features that are not robust (i.e. features that are not picked up by both GlaTE and ITVEO) are partially removed. This interpretation is supported by (1) the fact that both the total area (Fig. 5A) and the total volume (Fig. 5B) of the potential lakes detected by using the mean bedrock topography is lower than either of the GlaTE or ITVEO results, and (2) visual inspection of the individual results (e.g. Fig. 6).

In general, ITVEO tends to produce more pronounced topographical features whilst the subglacial topography generated with GlaTE is smoother (Fig. 6B). This difference in smoothness results in a higher number of potential lakes being detected with ITVEO than with GlaTE (Fig. 6A) but since the additional lakes are generally small, they contribute little to the total volume of potential lakes (Fig. 5A). With an average depth of $32.2 \mathrm{~m}$, GlaTE also produces slightly deeper lakes than ITVEO (average depth $=26.3 \mathrm{~m}$ ) whilst the anticipated potential lake area is very similar (Fig. 5B).

The differences between GlaTE and ITVEO is dependent on the available GPR coverage. In particular, the two approaches show larger differences with increasing distance to GPR measurements (Fig. 6B). On glaciers with low GPR coverage, the differences can be large, with some cases showing estimated potential lake volumes differing by up to a factor of two (e.g. Glacier du Trient, SGI-ID B90-02; Glacier de Corbassière, B83-03; Unterer Theodulgletscher, B56-28; Bisgletscher, B5808; Hüfifirn, A51d-10; or Obers Ischmeer, A54l-31). In general, however, the total volume of potential lakes detected on a glacier-by-glacier basis by GlaTE or ITVEO is very similar, the comparison visualised in Figure 5C showing a correlation coefficient as high as $\mathrm{r}^{2}=0.96$

All of the above considerations indicate that although uncertainties still exist, our approach is reliable and robust in identifying potential glacier lakes that might emerge in future. 
https://doi.org/10.5194/esurf-2022-12

Preprint. Discussion started: 1 March 2022

(c) Author(s) 2022. CC BY 4.0 License.

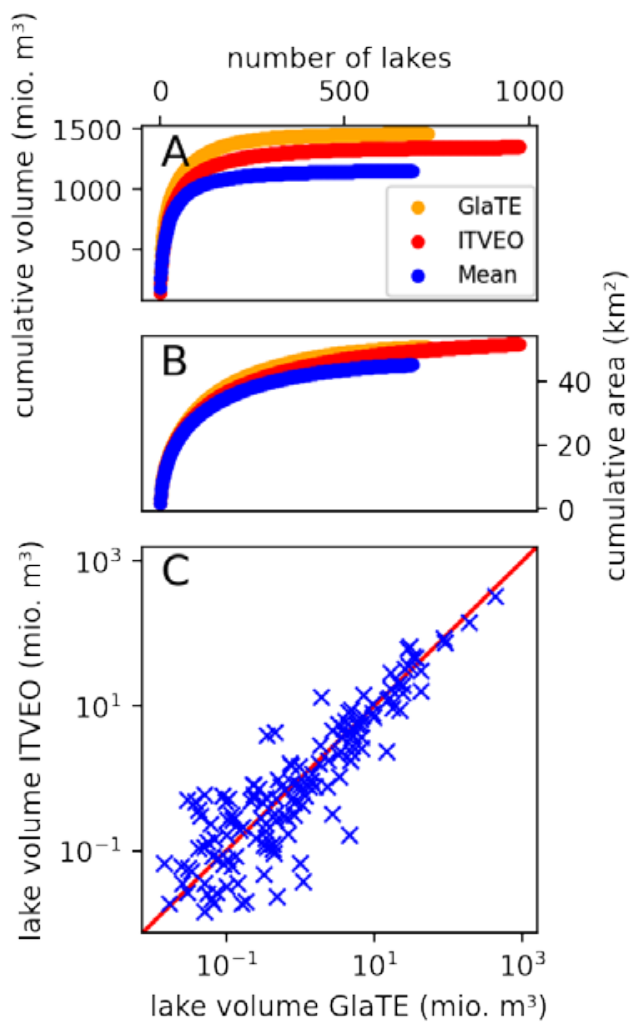

Figure 5 Cumulative (A) volume and (B) area of all potential lakes detected with GlaTE (orange), ITVEO (red), and the mean bedrock topography (blue). (C) Comparison of the volume of potential lakes per glacier detected with GlaTE and 515 ITVEO. Along the red line, the volume calculated with the two models is equal. Note the logarithmic scale. 
https://doi.org/10.5194/esurf-2022-12

Preprint. Discussion started: 1 March 2022

(c) Author(s) 2022. CC BY 4.0 License.
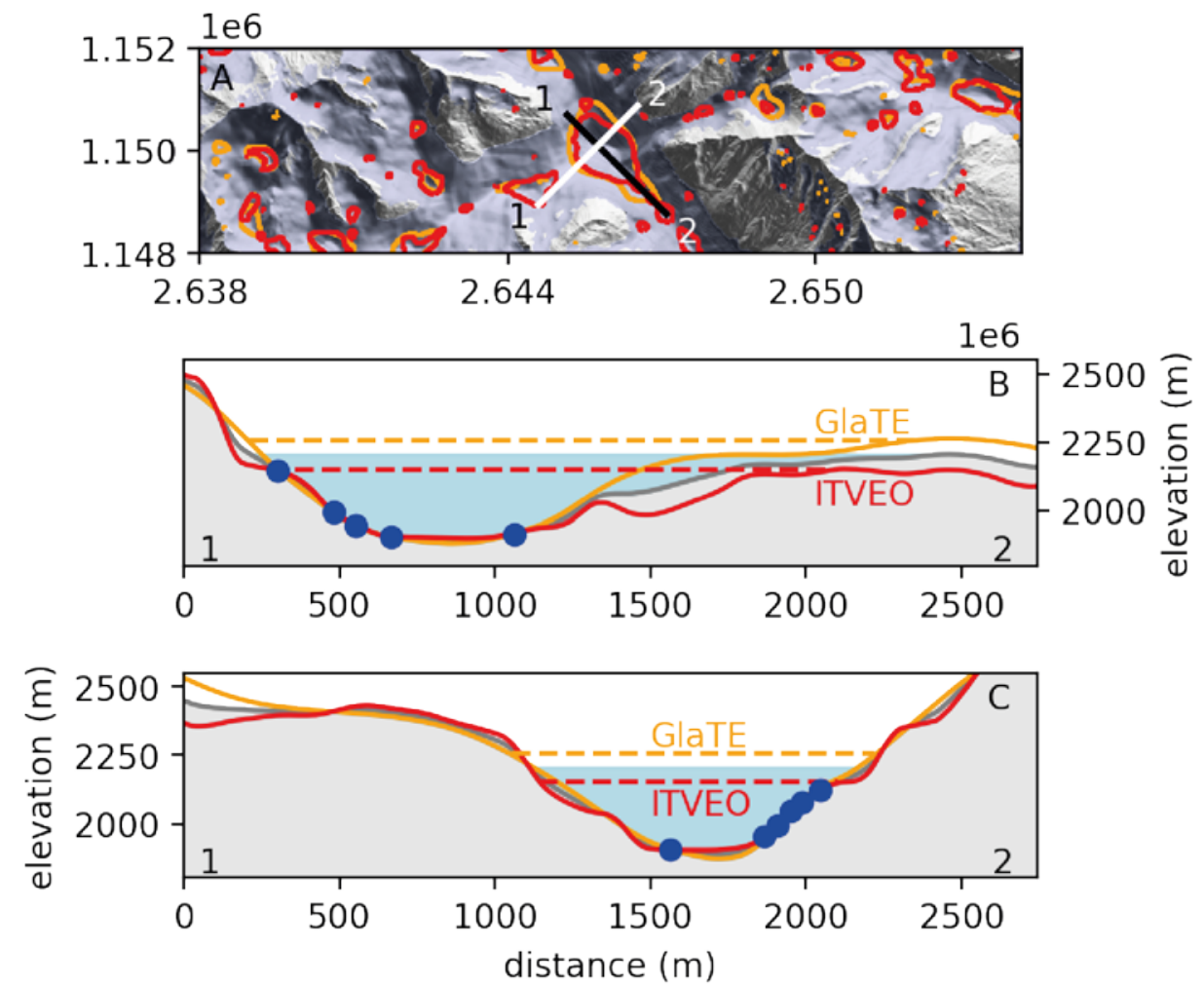

Figure 6 (A) Comparison between the potential lakes detected by GlaTE (orange) and ITVEO (red) in the Aletsch region. The glacier area of the SGI2016 is marked in blue. The black and white lines provide the locations of the profiles displayed in panels $\mathbf{B}$ and $\mathbf{C}$, respectively. (B-C) Illustration of the bedrock topography (orange: GlaTE; red: ITVEO; grey: mean) for the profiles given in panel A. GPR measurements are indicated (blue dots) together with the lake levels resulting from the three topographies (blue is the lake for the mean topography).

\subsection{Comparison to previous studies}

Our study is not the first one trying to quantify the emergence of future glacier lakes in the Swiss Alps. Linsbauer et al. (2012) applied the "Glacier bed Topography (GlabTop)" model to estimate the subglacial topography of the glaciers contained within the Swiss Glacier Inventory 2000 (Paul, 2007) and assumed future lakes to form in the detected bedrock overdeepenings. By applying a threshold for the lake area of $>10,000 \mathrm{~m}^{2}$, they reported that between 394 and 523 new lakes might eventually form if all glaciers were to disappear, corresponding to a total potential lake volume of between 1.2 and $1.6 \mathrm{~km}^{3}$ (the range in their results reflects two different procedures used to estimate the subglacial topography and the corresponding overdeepenings). With the same size threshold (i.e. when only considering lakes with an area $>10,000 \mathrm{~m}^{2}$ ), 
https://doi.org/10.5194/esurf-2022-12

Preprint. Discussion started: 1 March 2022

(c) Author(s) 2022. CC BY 4.0 License.

our results indicate 543 potential lakes for a total volume of $1.15[1.05,1.32] \mathrm{km}^{3}$. Considering that our estimates are based on a comprehensive set of direct ice thickness observations (cf. Sec. 2) whilst the results from Linsbauer et al. (2012) were only based on information of the surface topography, the results are remarkably close. Of note is also the fact that, similarly to our results, the largest potential lake detected by Linsbauer et al. (2012) is situated beneath Konkordiaplatz, at Grosser Aletschgletscher. Although the potential area of that lake estimated by Linsbauer et al. (2012) is about $1 \mathrm{~km}^{2}$ larger than the area estimated in our study $\left(2.5 \mathrm{~km}^{2}\right.$ compared to $\left.1.5 \pm 0.1 \mathrm{~km}^{2}\right)$, the mean depths are in very good agreement (Linsbauer et al., 2012, estimated $100 \mathrm{~m}$, whilst our study indicates 123 [88, 178] m). Although this comparison indicates that the total volume of potential future glacier lakes is somewhat smaller than previously estimated, it also shows that the methods used by Linsbauer et al. (2012) were skilful.

540 More recently, Gharehchahi et al. (2020) used an approach named "Volume and Topography Automation" to estimate the size and distribution of future glacier lakes in the Rhone catchment. They assessed the performance of their approach to be more reliable on glaciers larger than $5 \mathrm{~km}^{2}$, and found 125 potential future lakes with a total volume of $0.68 \mathrm{~km}^{3}$ beneath glaciers of this size class. These numbers are significantly smaller than the 307 potential lakes and the total volume of 0.84 $[0.74,1.01] \mathrm{km}^{3}$ we determine for the same glaciers. The same applies to the total area of these lakes: whilst Gharehchahi 545 et al. (2020) computed an area of $19.3 \mathrm{~km}^{2}$, we detected $27.4 \pm 4.5 \mathrm{~km}^{2}$. The opposite is true for the average lake depth. The potential lakes identified by Gharehchahi et al. (2020) are slightly deeper (average depth: $34.9 \mathrm{~m}$ ) than ours (30.5 [26.9, 36.7] m). Considering that - similarly as Linsbauer et al. (2012) -Gharehchahi et al. (2020) only used measured ice thicknesses for model validation but not as direct model input, we suggest that the extensive GPR data available for our study might have been helpful in identifying smaller overdeepenings. Of note is also that the largest lake identified by 550 Gharehchahi et al. (2020) lies beneath the terminus of Gornergletscher, with a predicted total volume of 96 mio. $\mathrm{m}^{3}$. This is more than twice as much as indicated by our results $\left(46.4\right.$ mio. $\mathrm{m}^{3}$ ). Since the potential area of this lake is similar between the two studies (1.6 vs $1.7 \pm 0.1 \mathrm{~km}^{2}$ ) and since the terminal area of Gornergletscher is reasonably well covered by GPR data (see Supplementary Figure S4 in Grab et al., 2021), it is likely that Gharehchahi et al. (2020) overestimated the depth of this lake.

\section{Conclusions}

We quantified the number, area, and volume of the potential new glacier lakes that may form in Switzerland due to ongoing glacier retreat. Relying on the recently released subglacial topography by Grab et al. (2021), we systematically detected subglacial overdeepenings and characterised them in terms of both location and shape. In contrast to previous estimates 560 (Linsbauer et al., 2012; Gharehchahi et al., 2020), our analysis is based on extensive GPR measurements which significantly increases the robustness of the results. In total, we detected 683 potential glacier lakes with a size larger than $5,000 \mathrm{~m}^{2}$ and a depth exceeding $5 \mathrm{~m}$. Together, they hold the potential of covering an area of $45.2 \pm 9.3 \mathrm{~km}^{2}$ and of 
https://doi.org/10.5194/esurf-2022-12

Preprint. Discussion started: 1 March 2022

(c) Author(s) 2022. CC BY 4.0 License.

containing a water volume of $1.16[1.05,1.32] \mathrm{km}^{3}$. These new lakes are mainly situated in the hydrological basin of the Rhone, which accounts for $70 \%$ of the total area and $79 \%$ of the total volume of all potential future glacier lakes detected in the Swiss Alps. By relying on results from the glacier evolution model GloGEM (Huss and Hock, 2015), we also assessed the timing by which these future lakes are likely to emerge. We show that by 2050, more than a hundred new glacier lakes might form depending on the climate scenario, potentially giving rise to a total lake volume of up to $0.19 \mathrm{~km}^{3}$. Whilst the mid-term evolution of the future glacier lakes shows little sensitivity to the climate scenario that will actually materialize, it might depend more critically on the local sediment inputs. With a first analysis, we estimate that up to one quarter of the new glacier lake volume might have re-filled with sediments by 2050 - the process being of particular importance for small lakes. The influence of the climate scenario will be much more prominent in the second half of this century. By 2100, climate scenarios implying high emissions suggest that up to $90 \%$ of the total volume of potential lakes might have formed, whilst only $23 \%$ of the volume might form if emissions were abated quickly, hence, slowing glacier recession. The results reiterate the rapid changes that have to be expected in alpine regions, and highlight that relatively little time is available to adapt to these changes. Whilst glacier lakes can be of high ecological relevance and might be attractive for a number of purposes ranging from water management to recreational use, they also bear some hazard potential - outbursts from glacier lakes being one of the most common and far-reaching hazards related to glaciers (Haeberli et al., 1989; Carrivick and Tweed, 2013). Our results may serve as a base to assess both positive and negative implications of these elements of our future landscapes.

\section{Data availability}

During review, the results generated within this study are available in digital format at https://drive.switch.ch/index.php/s/MV5hd1HS8AxrueM. This URL will be replaced with a DOI-handle in the event of the paper being accepted for publication.

\section{Author contributions}

DF and MH conceived the study. TS and RE performed the lake-volume calculations with the help of EH and DF. MH performed the GloGEM simulations and modelled the future sediment inputs. DF designed the figures, which were realized by TS, RE and MH. TS, DF, and MH drafted the manuscript, to which all authors contributed.

\section{Competing interests}

The contact author has declared that neither they nor their co-authors have any competing interests. 
https://doi.org/10.5194/esurf-2022-12

Preprint. Discussion started: 1 March 2022

(c) Author(s) 2022. CC BY 4.0 License.

\section{Bibliography}

Anacona, P. I., Kinney, J., Schaefer, M., Harrison, S., Wilson, R., Segovia, A., Mazzorana, B., Guerra, F., Farías, D., Reynolds, J. M., \& Glasser, N. F. (2018). Glacier protection laws: Potential conflicts in managing glacial hazards and adapting to climate change. Ambio, 47(8), 835-845.

Antoniazza, G., \& Lane, S. N. (2021). Sediment yield over glacial cycles: A conceptual model. Progress in Physical Geography: Earth and Environment, 45(6), 842-865.

Ballantyne, C. K. (2002). Paraglacial geomorphology. Quaternary Science Reviews, 21(18-19), 1935-2017.

Benn, D. I., \& Evans, D. J. (2010). Glaciers and Glaciation, 2nd ed. Hodder Education, London, ISBN: 9780340905791

Bogen, J., Xu, M., \& Kennie, P. (2015). The impact of pro-glacial lakes on downstream sediment delivery in Norway. Earth Surface Processes and Landforms, 40(7), 942-952.

Bolch T., Peters J., Yegorov A., Pradhan B., Buchroithner M., Blagoveshchensky V. (2012) Identification of potentially dangerous glacial lakes in the northern Tian Shan. In: Pradhan B., Buchroithner M. (eds) Terrigenous mass movements. Springer, Berlin, Heidelberg.

Brunner, M. I., Gurung, A. B., Zappa, M., Zekollari, H., Farinotti, D., \& Stähli, M. (2019). Present and future water scarcity in Switzerland: Potential for alleviation through reservoirs and lakes. Science of the Total Environment, 666, 1033-1047.

Buckel, J., Otto, J. C., Prasicek, G., \& Keuschnig, M. (2018). Glacial lakes in Austria - Distribution and formation since the Little Ice Age. Global and Planetary Change, 164, 39-51.

Carrivick, J. L., \& Tweed, F. S. (2021). Deglaciation controls on sediment yield: Towards capturing spatio-temporal variability. Earth-Science Reviews, 221, 103809.

Carrivick, J., \& Tweed, F. S. (2013). Proglacial lakes: character, behaviour and geological importance. Quaternary Science Reviews, 78, 34-52.

Čiamporová-Zat'ovičová, Z., \& Čiampor Jr, F. (2017). Alpine lakes and ponds-a promising source of high genetic diversity in metapopulations of aquatic insects. Inland waters, 7(1), 109-117.

615 Colonia, D., Torres, J., Haeberli, W., Schauwecker, S., Braendle, E., Giraldez, C., \& Gochachin, A. (2017). Compiling an inventory of glacier-bed overdeepenings and potential new lakes in de-glaciating areas of the Peruvian Andes: Approach, first results, and perspectives for adaptation to climate change. Water, 9(5), 336.

Compagno, L., Eggs, S., Huss, M., Zekollari, H., \& Farinotti, D. (2021). Brief communication: Do 1.0, 1.5, or $2.0^{\circ} \mathrm{C}$ matter for the future evolution of Alpine glaciers? The Cryosphere, 15(6), 2593-2599.

620 Cook, S. J., \& Swift, D. A. (2012). Subglacial basins: Their origin and importance in glacial systems and landscapes. EarthScience Reviews, 115(4), 332-372.

Costa, A., Anghileri, D., \& Molnar, P. (2018). Hydroclimatic control on suspended sediment dynamics of a regulated Alpine catchment: a conceptual approach. Hydrology and Earth System Sciences, 22(6), 3421-3434. 
https://doi.org/10.5194/esurf-2022-12

Preprint. Discussion started: 1 March 2022

(c) Author(s) 2022. CC BY 4.0 License.

Delaney, I., Bauder, A., Huss, M., \& Weidmann, Y. (2018b). Proglacial erosion rates and processes in a glacierized catchment in the Swiss Alps. Earth Surface Processes and Landforms, 43(4), 765-778.

Delaney, I., Bauder, A., Werder, M. A., \& Farinotti, D. (2018a). Regional and annual variability in subglacial sediment transport by water for two glaciers in the Swiss Alps. Frontiers in Earth Science, 6, 175.

Drenkhan, F., Guardamino, L., Huggel, C., \& Frey, H. (2018). Current and future glacier and lake assessment in the deglaciating Vilcanota-Urubamba basin, Peruvian Andes. Global and Planetary Change, 169, 105-118.

Ehrbar, D., Schmocker, L., Vetsch, D. F., \& Boes, R. M. (2018). Hydropower potential in the periglacial environment of Switzerland under climate change. Sustainability, 10(8), 2794.

Emmer, A., Klimeš, J., Mergili, M., Vilímek, V., \& Cochachin, A. (2016). 882 lakes of the Cordillera Blanca: An inventory, classification, evolution and assessment of susceptibility to outburst floods. Catena, 147, 269-279.

Emmer, A., Merkl, S., \& Mergili, M. (2015). Spatiotemporal patterns of high-mountain lakes and related hazards in western

Austria. Geomorphology, 246, 602-616.

Emmer, A., Vilímek, V., Klimeš, J., \& Cochachin, A. (2014). Glacier retreat, lakes development and associated natural hazards in Cordilera Blanca, Peru. In: Shan W., Guo Y., Wang F., Marui H., Strom A. (eds) Landslides in cold regions in the context of climate change. Environmental Science and Engineering. Springer, Cham.

Esri Inc (2020). ArcGis Pro(Version 2.7.1) Hydrology Toolset: Fill (Spatial Analyst). Esri Inc. https://www.esri.com/enus/arcgis/products/arcgis-pro/overview. Last accessed: 10.02.2022.

Eyring, V., Bony, S., Meehl, G. A., Senior, C. A., Stevens, B., Stouffer, R. J., \& Taylor, K. E. (2016). Overview of the Coupled Model Intercomparison Project Phase 6 (CMIP6) experimental design and organization. Geoscientific Model Development, 9(5), 1937-1958.

Farinotti, D., Brinkerhoff, D. J., Clarke, G. K., Fürst, J. J., Frey, H., Gantayat, P., Gillet-Chaulet, F., Girard, C., Huss, M.,

Leclerq, P. W., Linsbauer, A., Machguth, H., Martin, C., Maussion, F., Morlighem, M., Mosbeux, C., Pandit, A., Portmann, A., Rabatel, A., Ramsankaran, R., Reerink, T. J., Sanchez, O., Stentoft, P. A., Kumari, S., van Pelt, W. J., Anerson, B., Benham, T., Binder, D., Dowdeswell, J. A., Fischer, A., Helfricht, K., Kutuzov, S., Lavrentiev, I., McNabb, R., Gudmundsson, G. H., Li, H., \& Andreassen, L. M. (2017). How accurate are estimates of glacier ice thickness? Results from ITMIX, the Ice Thickness Models Intercomparison eXperiment. The Cryosphere, 11(2), 949-970.

Farinotti, D., Brinkerhoff, D., Fuerst, J., Gantayat, P., Gillet-Chaulet, F., Huss, M., Leclercq, P. W., Linsbauer, A., Machguth, H., Martin, C., Maussion, F., Morlighem, M., Mosbeux, C., Pandit, A., Portmann, A., Rabael, A., Ramsakaran, R., Reerink, T. J., Robo, E., Rouges, E., Tamre, E., van Pelt, W. J., Werder, M. A., Azam, M. F., Li, H., \& Andreassen, L. M. (2021). Results from the Ice Thickness Models Intercomparison eXperiment phase 2. Frontiers in Earth Science, 8, 484.

Farinotti, D., Pistocchi, A., \& Huss, M. (2016). From dwindling ice to headwater lakes: could dams replace glaciers in the

European Alps? Environmental Research Letters, 11(5), 054022.

Farinotti, D., Round, V., Huss, M., Compagno, L., \& Zekollari, H. (2019). Large hydropower and water-storage potential in future glacier free-basins. Nature, 575(7782), 341-344. 
https://doi.org/10.5194/esurf-2022-12

Preprint. Discussion started: 1 March 2022

(c) Author(s) 2022. CC BY 4.0 License.

Frey, H., Haeberli, W., Linsbauer, A., Huggel, C., \& Paul, F. (2010). A multi-level strategy for anticipating future glacier lake formation and associated hazard potentials. Natural Hazards and Earth System Sciences, 10(2), 339-352.

Galluccio, A. (1998). I nuovi laghi proglaciali lombardi. Terrra Glacialis, 1, 133-151.

Gardelle, J., Arnaud, Y., \& Berthier, E. (2011). Contrasted evolution of glacial lakes along the Hindu Kush Himalaya mountain range between 1990 and 2009. Global and Planetary Change, 75(1-2), 47-55.

Geilhausen, M., Morche, D., Otto, J. C., \& Schrott, L. (2013). Sediment discharge from the proglacial zone of a retreating Alpine glacier. Zeitschrift für Geomorphologie, 57(2), 29-53.

Gharehchahi, S., James, W. H., Bhardwaj, A., Jensen, J. L., Sam, L., Ballinger, T. J., \& Butler, D. R. (2020). Glacier ice thickness estimation and future lake formation in Swiss southwestern Alps-The upper Rhône catchment: A VOLTA application. Remote Sensing, 12(20), 3443.

Grab, M., Mattea, E., Bauder, A., Huss, M., Rabenstein, L., Hodel, E., E; Linsbauer, A., Langhammer, L., Schmid, L., Church, G., Hellmann, G., Délèze, K., Schaer, P., Lathion, P., Farinotti, D., \& Maurer , H. (2021). Ice thickness distribution and glacier bed topography of Switzerland based on ground penetrating radar. Journal of Glaciology, 67(266), 1074-1092.

Haeberli, W., Alean, J. C., Müller, P., \& Funk, M. (1989). Assessing risks from glacier hazards in high mountain regions: some experiences in the Swiss Alps. Annals of Glaciology, 13, 96-102.

Haeberli, W., Buetler, M., Huggel, C., Friedli, T. L., Schaub, Y., \& Schleiss, A. J. (2016). New lakes in deglaciating highmountain regions - opportunities and risks. Climatic change, 139(2), 201-214.

Herman, F., Beyssac, O., Brughelli, M., Lane, S. N., Leprince, S., Adatte, T., Lin, J. Y. Y., Avouac, J., \& Cox, S. C. (2015). Erosion by an Alpine glacier. Science, 350(6257), 193-195.

Hersbach, H., Bell, B., Berrisford, P., Hirahara, S., Horányi, A., Muñoz-Sabater, J., Nicolas, J., Peubey, C., Radu, R., Schepers, D., Simmons, A., Soci, C., Abdalla, S., Abellan, X., Balsamo, G., Bechtold, P., Biavati, G., Bidlot, J., Bonavita, M., De Chiara, G., Dahlgreen P., Dick D., Diamantakis M., Dragani R., Flemming, J., Forbes, R., Fuentes, M., Geer, A., Haimberger, L., Healy, S., J., Hogan, R. J., Hólm, E., Janisková,M., Keeley, S., Laloyaux, P., Lopez, P., Lupu, C., Radnoti, G., de Rosnay, P., Rozum, I., Vamborg, F., Villaume, S., \& Thépaut, J.N. (2020). The ERA5 global reanalysis. Quarterly Journal of the Royal Meteorological Society, 146(730), 1999-2049.

Hinderer, M., Kastowski, M., Kamelger, A., Bartolini, A., \& Schlunegger, A. (2013). River loads and modern denudation of the Alps - A review. Earth-Science Reviews, 118, 11-44.

Hock, R., Rasul, G., Adler, C., Cáceres, B., Gruber S., Hirabayashi, Y., Jackson M., Kääb, A., Kang, S., Kutuzov, S., Milner A., Mulau. O., Morin S., Orlove B., \& Steltzer H. (2019). High mountain areas. In: IPCC Special Report on the ocean and cryosphere in a changing climate. Pörtner, H. O., Roberts, D. C., Masson-Delmotte, V., Zhai, P., Tignor, M., Poloczanska, E., Mintenbeck, K., Alegría, A., Nicolai, M., Okem, A., Petzold, J., Rama, B., Weyer, N.M. (eds.). In press.

690 Huggel, C., Kääb, A., Haeberli, W., Teysseire, P., \& Paul, F. (2002). Remote sensing based assessment of hazards from glacier lake outbursts: a case study in the Swiss Alps. Canadian Geotechnical Journal, 39(2), 316-330. 
https://doi.org/10.5194/esurf-2022-12

Preprint. Discussion started: 1 March 2022

(c) Author(s) 2022. CC BY 4.0 License.

Hugonnet, R., McNabb, R., Berthier, E., Menounos, B., Nuth, C., Girod, L., Farinotti, D., Huss, M., Dussaillant, I., Brun, F., \& Kääb, A. (2021). Accelerated global glacier mass loss in the early twenty-first century. Nature, 592, 726-731.

Huss, M., \& Farinotti, D. (2012). Distributed ice thickness and volume of all glaciers around the globe. Journal of

Huss, M., \& Hock, R. (2015). A new model for global glacier change and sea-level rise. Frontiers in Earth Science 3, 54.

Huss, M., \& Hock, R. (2018). Global-scale hydrological response to future glacier mass loss. Nature Climate Change, 8(2), 135-140.

Huss, M., Jouvet, G., Farinotti, D., \& Bauder, A. (2010). Future high-mountain hydrology: a new parameterization of glacier retreat. Hydrology and Earth System Sciences, 14(5), 815-829.

Iken, A., \& Bindschadler, R. A. (1986). Combined measurements of subglacial water pressure and surface velocity of Findelengletscher, Switzerland: conclusions about drainage system and sliding mechanism. Journal of Glaciology, 32(110), 101-119.

IPBES. (2019). Retrieved from Global assessment report on biodiversity and ecosystem services of the Intergovernmental Science-Policy Platform on Biodiversity and Ecosystem Services, Díaz S., Settele, J., Brondízio, E. S, Ngo, H. T., Guèze, M., Agard, J., Arneth, A., Balvanera, P., Brauman, K. A, Butchart, S.H: M., Chan, K. M. A., Garibaldi, L. A., Ichii, K., Liu, J., Subramanian, S. M., Midgley, G.F., P. Miloslavich, P., Molnár, Z., Obura, D., A. Pfaff, A., Polasky, S., Purvis, A., Razzaque, J., Reyers, B., Roy Chowdhury, R., Shin, Y. J., Visseren-Hamakers, I. J., Willis, K. J., \& C. N. Zayas C. N.(eds.). IPBES secretariat, Bonn, Germany. 56 pp.

710 Kapitsa, V., Shahgedanova, M., Machguth, H., Severskiy, I., \& Medeu, A. (2017). Assessment of evolution and risks of glacier lake outbursts in the Djungarskiy Alatau, Central Asia, using Landsat imagery and glacier bed topography modelling. Natural Hazards and Earth System Science, 17(10), 1837-1856.

Kellner, E. (2019). Social acceptance of a multi-purpose reservoir in a recently deglaciated landscape in the Swiss Alps. Sustainabilty, 11(14), 3819.

715 Kellner, E. (2021). The controversial debate on the role of water reservoirs in reducing water scarcity. Wiley Interdisciplinary Reviews: Water, 8(3), e1514.

Kellner, E., \& Brunner, M. I. (2021). Reservoir governance in world's water towers needs to anticipate multi-purpose use. Earths Future, 9(1), e2020EF001643.

Komori, J. (2008). Recent expansions of glacial lakes in the Bhutan Himalayas. Quaternary International, 184(1), 177-186.

Lane, S. M., Bakker, M., Gabbud, C., Micheletti, N., \& Saugy, J. N. (2017). Sediment export, transient landscape response and catchment-scale connectivity following rapid climate warming and Alpine glacier recession. Geomorphology, 277, 210-227.

Langhammer, L., Grab, M., Bauder, A., \& Maurer, H. (2019a). Glacier thickness estimations of alpine glaciers using data and modelling constraints. The Cryosphere, 13(8), 2189-2202. 
https://doi.org/10.5194/esurf-2022-12

Preprint. Discussion started: 1 March 2022

(c) Author(s) 2022. CC BY 4.0 License.

Langhammer, L., Rabenstein, L., Schmid, L., Bauder, A., Grab, M., Schaer, P., \& Maurer, H. (2019b). Glacier bed surveying with helicopter-borne dual-polarization ground-penetrating radar. Journal of Glaciology, 65(249), 123-135.

Li, D., Lu, X., Overeem, I., Walling, D. E., Syvitski, J., Kettner, A. J., Bookhagen, B., Zhou, Y., \& Zhang, T. (2021). Exceptional increases in fluvial sediment fluxes in a warmer and wetter High Mountain Asia. Science, 374(6567), 599-603.

Linsbauer, A., Frey, H., Haeberli, W., Machgut, H., Azam, M. F., \& Allen, S. (2016). Modelling glacier-bed overdeepenings and possible future lakes for the glaciers in the Himalaya—Karakoram region. Annals of Glaciology, 57(71), 119-130.

Linsbauer, A., Huss, M., Hodel, E., Bauder, A., Fischer, M., Weidmann, Y., \& Schmassmann E. (2021). The new Swiss Glacier Inventory SGI2016: a detailed cartographic representation of Swiss glacier extent and supraglacial debris-cover. Frontiers in. Earth Science.9, 774.

Linsbauer, A., Paul, F., \& Haeberli. (2012). Modeling glacier thickness distribution and bed topography over entire mountain ranges with GlabTop: Application of a fast and robust approach. Journal of Geophysical Research: Earth Surface, 117, F00307.

MacGregor, K. R., Anderson, R. S., \& Waddington, E. D. (2009). Numerical modeling of glacial erosion and headwall processes in alpine valleys. Geomorphology, 103(2), 189-204.

Magnin, F., Haeberli, W., Linsbauer, A., Deline, P., \& Ravanel, L. (2020). Estimating glacier-bed overdeepenings as possible sites of future lakes in the de-glaciating Mont Blanc massif (Western European Alps). Geomorphology, 350, 106913.

Marzeion, B., Hock, R., Anderson, B., Bliss, A., Champollion, N., Fujita, K., Huss, M., Immerzeel, W. W., Kraaijenbrink, P., Malles, J H., Maussion, F., Radić, V., Rounce, D. R., Sakai, A., Shannon, S., van de Wal, R., \& Zekollari, H. (2020). Partitioning the uncertainty of ensemble projections of global glacier mass change. Earth's Future, 8(7), e2019EF001470.

Marzeion, B., Kaser, G., Maussion, F., \& Champollion, N. (2018). Limited influence of climate change mitigation on shortterm glacier mass loss. Nature Climate Change, 8(4), 305-308.

Meinshausen, M., Nicholls, Z. R., Lewis, J., Gidden, M. J., Vogel, E., Freund, M., Beyerle, U., Gessner, C., Nauels, A., Bauer, N., Canadell, J. G., Daniel, J. S., John, A., Krummel, P. B., Luderer, G., Meinshausen, N., Montzka, S. A., Rayner, P. J., Reimann, S., Smith, S. J., van den Berg, M., Velders, G. J., Vollmer, M. K., \& Wang, R. H. (2020). The shared socioeconomic pathway (SSP) greenhouse gas concentrations and their extensions. Geoscientific Model Development, 13(8), 3571-3605.

Micheletti, N., \& Lane, S. N. (2016). Water yield and sediment export in small, partially glaciated Alpine watersheds in a warming climate. Water Resources Research, 52(6), 4924-4943.

Mölg, N., Huggel, C., Herold, T., Storck, F., Allen, S., Haeberli, W., Schaub, Y., \& Odermatt, D. (2021). Inventory and 755 evolution of glacial lakes since the Little Ice Age: lessons from the case of Switzerland. Earth Surface Processes and Landforms, 46(13), 2551-2564 
https://doi.org/10.5194/esurf-2022-12

Preprint. Discussion started: 1 March 2022

(c) Author(s) 2022. CC BY 4.0 License.

NELAK (2013): Neue Seen als Folge des Gletscherschwundes im Hochgebirge - Chancen und Risiken. Formation des nouveux lacs suite au recul des glaciers en haute montagne - chances et risques. Forschungsbericht NFP 61. Haeberli, W., Bütler, M., Huggel, C., Müller, H. \& Schleiss, A. (eds). Zurich, vdf Hochschulverlag AG at ETH Zurich, 300 pp.

Orlove, B., Wiegandt, E., \& Luckmann, B. H. (2008). Darkening peaks: glacier retreat, science, and society. University of California Press, ISBN: 9780520253056

Paul, F. (2007), The new Swiss glacier inventory 2000: Application of remote sensing and GIS, PhD thesis, Schriftenreihe Physische Geographie, University of Zurich, Zurich, Switzerland.

Petrov, M. A., Sabitov, T. Y., Tomashevskaya, I. G., Glazirin, G. E., Chernomorets, S. S., Savernyuk, E. A., Tutubalina, O. V., Petrakov, D. A., Sokolov, L. S., Dokukin, M. D., Mountrakis, G., Ruiz-Villanueva, V., \& Stoffel, M. (2017). Glacial lake inventory and lake outburst potential in Uzbekistan. Science of the Total Environment, 592, 228-242.

Purdie, H. (2013). Glacier retreat and tourism: Insights from New Zealand. Mountain Research and Development, 33(4), 463-472.

Rutishauser, A., Maurer, H., \& Bauder, A. (2016). Helicopter-borne ground-penetrating radar investigations on temperate alpine glaciers: A comparison of different systems and their abilities for bedrock mapping. Geophysics, 81(1), WA119WA129.

Salerno, F., Gambelli, S., Viviano, G., Thakuri, S., Guyennon, N., D'Agata, C., Diolauti, G., Smiraglia, C., Stefani, F., Bocchioloa, D., \& Tartari, G. (2014). High alpine ponds shift upwards as average temperatures increase: A case study of the Ortles-Cevedale mountain group (Southern Alps, Italy) over the last 50 years. Global and Planetary Change, 120, 8191.

Shugar, D. H., Burr, A., Haritashaya, U., Kargel, J. S., Watson, C. S., Kennedy, M. C., Bevington, A. R., Betts, R. A., Harrison, S., \& Strattmann, K. (2020). Rapid worldwide growth of glacier lakes since 1990. Nature Climate Change, 10(10), 939-945.

Swisstopo. (2019). Bundesamt für Landestopografie swisstopo, swissALTI3D - Das hochaufgelöste Terrainmodell der $780 \quad$ Schweiz. Ausgabebericht 2019.

Swisstopo. (2021). Bundesamt für Landestopografie swisstopo Luftbilder. Karten der Schweiz - Schweizerische Eidgenossenschaft - map.geo.admin.ch. Last accessed: 10.02.2022

Tiberti, R., Buscaglia, F., Callieri, C., Regora, M., Tartari, G., \& Sommaruga, R. (2019). Food Web complexity of high mountain lakes is largely affected by glacial retreat. Ecosystems, 23(5), 1093-1116.

785 Veh, G., Korup, O., Roessner, S., \& Walz, A. (2018). Detecting Himalayan glacial lake outburst floods from Landsat time series. Remote Sensing of Environment, 207, 84-97.

Veh, G., Korup, O., von Specht, S., Roessner, S., \& Walz, A. (2019). Unchanged frequency of moraine-dammed glacial lake outburst floods in the Himalaya. Nature Climate Change, 9(5), 379-383. 
https://doi.org/10.5194/esurf-2022-12

Preprint. Discussion started: 1 March 2022

(c) Author(s) 2022. CC BY 4.0 License.

Viani, C., Giardino, M., Huggel, C., Perotti, L., \& Mortara, G. (2016). An overview of glacier lakes in the Western Italian Alps from 1927 to 2014 based on multiple data sources (historical maps, orthophotos and reports of the glaciological surveys). Geografia Fisica e Dinamica Quaternaria, 39(2), 203-214.

Viani, C., Machguth, H., Huggel, C., Godio, A., Franco, D., Perotti, L., \& Giardino M. (2020). Potential future lakes from continued glacier shrinkage in the Aosta Valley Region (Western Alps, Italy). Geomorphology, 355, 107068.

Volpi, E., Di Lazzaro, M., Bertola, M., Viglione, A., \& Fiori, A. (2018). Reservoir effects on flood peak discharge at the 795 catchment scale. Water Resources Research, 54(11), 9623-9636.

Wang, X., Guo, X., Yang, C., Liu, Q., Wei, J., Zhang, Y., Liu, S., Zhang, Y., Jiang, Z., \& Tang, Z. (2020). Glacial lake inventory of high-mountain Asia in 1990 and 2018 derived from Landsat images. Earth System Science Data, 12(3), 21692182.

Welling, J. T., Árnason, D., \& Ólafsdottír, R. (2015). Glacier tourism: a scoping review. Tourism Geographies, 17(5), 635662.

Welty, E., Zemp, M., Navarro, F., Huss, M., Fürst, J. J., Gärtner-Roer, I., Landmann, J., Machguth, H., Naegeli, K., Andreassen, L. M., Farinotti, D., Li, H., \& GlaThiDa Contributors. (2020). Worldwide version-controlled database of glacier thickness observations. Earth System Science Data, 12(4), 3039-3055.

Zekollari, H., Huss, M., \& Farinotti, D. (2019). Modelling the future evolution of glaciers in the European Alps under the EURO-CORDEX RCM ensemble. The Cryosphere, 13(4), 1125-1146.

Zekollari, H., Huss, M., \& Farinotti, D. (2020). On the imbalance and response time of glaciers in the European Alps. Geophysical Research Letters, 47(2), e2019GL085578

Zhang, G., Yao, T., Xie, H., Wang, W., \& Yang, W. (2015). An inventory of glacial lakes in the Third Pole region and their changes in response to global warming. Global and Planetary Change, 131, 148-157.

810 Zhang, T., Wang, W., Gao, T., An, B., \& Yao, T. (2022). An integrative method for identifying potentially dangerous glacial lakes in the Himalayas. Science of the total Environment, 806, 150442.

Zheng, G., Allen, S. K., Bao, A., Ballesteros-Cánovas, J. A., Huss, M., Zhang, G., Li, J., Jiang, L., Chen, W., \& Stoffel, M. (2021). Increasing risk of glacial lake outburst floods from future Third Pole deglaciation. Nature Climate Change, 11(5), 411-417. 